\title{
An Evaluation of a Worksite Diabetes Education Program for Employees with Diabetes at a Large Urban Medical Center
}

\author{
Susan Renda \\ Baltimore, MD \\ BS, University of Virginia, 1980 \\ MS, University of Maryland, 1989 \\ A Capstone presented to the Graduate Faculty \\ of the University of Virginia in Candidacy for the Degree of \\ Doctorate of Nursing Practice
}

\author{
School of Nursing \\ University of Virginia \\ May, 2014
}

On my honor as a student, I have neither given nor received unauthorized aid on this paper. Susan Renda 


\begin{abstract}
Strategies to improve health and diabetes self-management need to increase as the number of people with diabetes increases. In the worksite, employers experience an increase in number of employees with diabetes that leads to rising healthcare costs and impairments to productivity. Diabetes education can be delivered at the worksite as employers support interventions to help employees. Using Diffusion of Innovations Theory (Rogers, 1995) as a guide, a worksite diabetes education program was instituted as a pilot project at a large urban medical center. Employees were encouraged to come to the Diabetes Center at the medical institution for diabetes education with individual appointments or classes specifically for employees. Twenty participants successfully completed diabetes education with a certified diabetes educator. Participants chose a diabetes self-management goal and could anonymously evaluate their satisfaction with the program. Glycemic control measured by glycosylated hemoglobin $(\mathrm{A} 1 \mathrm{C})$, days absent from work, and number of hospital/emergency department visits from three months before the education were compared to three months following the education using dependent t-tests. Mean A1C declined significantly from $8.5 \%$ to $7.5 \%$. Over half of the participants attained at least $50 \%$ progress towards their chosen self-management goal and 17 completed evaluations which indicated full satisfaction with the education. The number of days absent trended downward, but longer observation may be necessary to determine statistically significant reduction in days absent and improvement in hospital/emergency room visit occurrence. The positive clinical results of this pilot projects suggest that diabetes
\end{abstract}


worksite education is effective at the medical institution and could continue to reach more employees. Further study is recommended with a larger number of employees and increased length of time. The focus of study also could include examination of comorbid conditions and attention to groups most at risk. 


\section{Table of Contents}

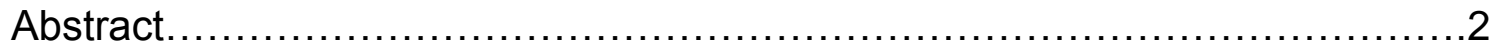

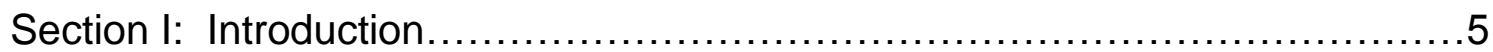

The Problem

Background

Theoretical Framework

Purpose and Rationale

Question

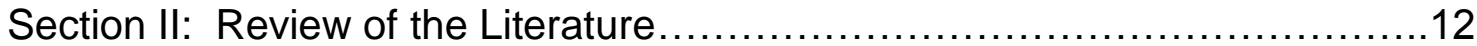

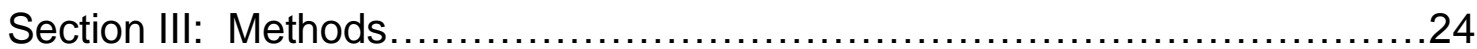

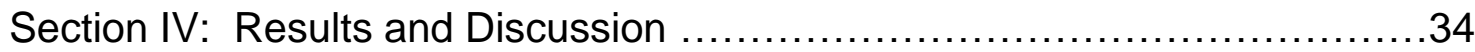

Results

Discussions

Implications

Conclusion

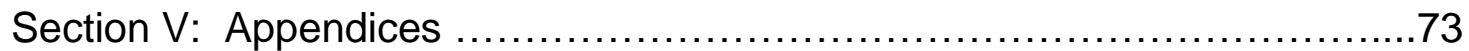

Appendix A Tables........................................... 74

Appendix B Figures.......................................... 87

Appendix C Program materials...................................93

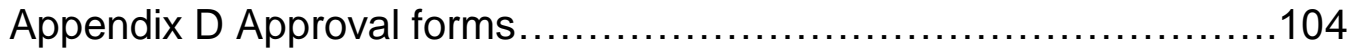


An Evaluation of a Worksite Diabetes Education Program for Employees with Diabetes at a Large Urban Medical Center

\section{Introduction}

Diabetes presents a serious challenge to human health and health care delivery. Over 25 million people or $8.3 \%$ of the population in the United States have diabetes and this proportion continues to grow. In 2010, 1.9 million people aged 20 years or older were newly diagnosed with diabetes (Centers for Disease Control, 2011). Diabetes is the leading cause of blindness, nontraumatic lower extremity amputation, and renal failure. Additionally, individuals diagnosed with diabetes are two to three times more likely as people without diabetes to have coronary and cerebral vascular disease.

Complications from diabetes have obvious human costs to quality and quantity of life, and also are an economic burden. In 2012, the estimated costs from diabetes totaled 245 billion dollars in direct and indirect costs (American Diabetes Association, 2013). Indirect costs include absenteeism from work, reduced productivity, and early death and disability. Diabetes accounts for 15 million work days missed, 120 million work days with decreased performance, and 107 million work days lost due to disability from diabetes complications. The absenteeism rate for people with diabetes is $0.8 \%$ higher than for people without diabetes. The highest per capita productivity loss from absenteeism occurs among men ages 45 to 53 (Centers for Disease Control, 2011). People with diabetes may not have a work absence, but be less productive because of illness. Lowered productivity is a phenomenon called "presenteeism" (Boles, Pelletier, \& Lynch, 2004). 
As the human and financial costs rise due to the increasing number of people with diabetes and its related complications, there are concerns that the medical resources to care for this complex population could overwhelm the healthcare system (HealthyPeople.gov, 2012). To confront the challenges that lie ahead, Healthy People 2020 has established the goal to "reduce the disease and economic burden of diabetes mellitus (DM) and improve the quality of life for all persons who have, or are at risk for DM" (HealthyPeople.gov, 2012, D-14). In 2008, 56.8\% of adults with diabetes reported receiving some formal diabetes education. A Healthy People 2020 goal is to increase the proportion of people with diabetes who receive formal diabetes education to $66.8 \%$. In its 2012 position statement, the American Diabetes Association (ADA) also emphasized the importance of patient self-management education to prevent and reduce complications (ADA, 2012).

Nurses are in a unique position to help reach the goal of increased diabetes education (Hunt, 2013). Nurses obtain patient education skills as part of their nursing education that may be used to assist individuals living with diabetes, their significant others, and family members to understand and manage diabetes. Nurses are present in multiple inpatient and outpatient settings, including the worksite, where diabetes education may be presented in-person (Philis-Tsimikas \& Gallo, 2014). They also are prepared to provide education and support via telephone or other web-based formats. Therefore it is clear that nurses play an important role in efforts to lessen the health and economic consequences associated with diabetes by helping people manage the disease (Carloti, Lavigne, Stone,Tortoretti, \& Chiverton, 2001; Philis-Tsimikas \& Gallo, 2014). 
Nurse-led patient self-management education has been associated with positive patient outcomes. Tshiananga, Kocher, Weber, Erny-Albrecht, Berndt, and Neeser (2012) published their findings from a meta-analysis of nurse-led diabetes selfmanagement education (DSME) and its impact on A1C (glycated hemoglobin) and cardiovascular risk factors. $\mathrm{A} 1 \mathrm{C}$ is the laboratory blood analysis of the hemoglobin molecule to detect hemoglobin $\mathrm{A} 1 \mathrm{C}$ which is related to the glucose concentration around the red blood cell during its 120 day lifespan (Higgins, 2012). Tshiananga, et al. (2012) identified thirty-four randomized controlled trials (RCTs) from relevant literature from 1999 to 2009. DSME sessions varied in frequency and length, but were always delivered by trained nurses. The RCTs included either type 1 diabetes, type 2 diabetes, or both. Studies concluded that the DSME given by the nurses was beneficial in significantly reducing mean $\mathrm{A} 1 \mathrm{C}$ by $0.7 \%$ versus $0.21 \%$ for those given usual care. Measurements of cardiovascular risk factors of elevated cholesterol and blood pressure were also reduced, especially in males. The authors recommended the development of more DSME programs including those designed to meet the specific needs of a variety of populations.

Employees with diabetes in the workplace are a growing population (Centers for Disease Control, 2011). This study evaluated a worksite diabetes education program at a large urban medical center that was designed to improve employees' awareness of and access to diabetes education. Previously, no similar educational programming had been available to employees of the medical center. The program had an evaluation component that evaluated $\mathrm{A} 1 \mathrm{C}$, days absent from work, the number of emergency room and hospital visits, self-management goal attainment, and participant satisfaction with 
the education. The evaluation can guide continued development of employee education at the medical center. The Diffusion of Innovations Theory (Rogers, 1995) served as the theoretical framework to structure the steps involved in developing, implementing, and evaluating the employee worksite diabetes education program.

\section{Theoretical Framework}

Everett Rogers' Diffusion of Innovations (DOI) theory provides a model which can be used to examine the process by which an innovation or new idea is accepted or rejected by a group over time (Rogers, 1995). The theory assumes that people are at different phases in the adoption process and it is important to identify characteristics of those people in order to better implement strategies that meet their needs (National Cancer Institute, 2005).

DOI has five major steps (See Figure 1) beginning with innovation development which involves the planning, formative research, and testing. Next, in the dissemination stage, the innovation is taught and transferred through communication channels to the users. The users adopt or do not adopt the innovation and do this at different speeds, meaning some are quick to utilize the innovation and are "early adopters" and others take more time or are "laggards". If adopted, the users implement the new practice with increased knowledge and improved self-efficacy. Once implemented, the innovation needs to be maintained to remain sustainable (Edberg, 2007). DOI is dependent on assessment of the intended group and communication channels within and directed towards that group.

The features of an innovation determine if and how it is adopted. The rate of adoption is dependent on features of relative advantage, compatibility, complexity, 
trialability, and observability. Relative advantage is whether the innovation will be perceived as better than what came before. For example, if a worksite diabetes education program offers a new, more useful way to help employees as compared to any previous program or if there was no program in place before, the employees have fewer problems adopting the worksite diabetes education program. Compatibility is how the innovation matches with existing values and needs. At the medical institution, it is important to have productive healthy employees and avenues to keep employees with diabetes healthy. The diabetes center is a resource present at the medical institution with an accessible program. Complexity is how difficult the innovation is to understand. Employees are instructed how to access the education and the education program CDE's are able to work with different learners to enhance their understanding. If the innovation is done initially on a limited basis or as an experiment as is being done with this education program, it has trialability. Observability is the degree to which the innovation or the results can be seen and communicated (Rogers, 1995). The measure of observability is the evaluation of the efficacy of the worksite diabetes education program. The efficacy is measured in outcomes such as change in $\mathrm{A} 1 \mathrm{C}$, absenteeism, number of hospital/emergency room visits, and attainment of selfmanagement goals. (See Figure 1) 


\begin{tabular}{|c|c|}
\hline Innovation development- & $\begin{array}{l}\text { Development of the diabetes } \\
\text { education program, including } \\
\text { assessment, planning, and review of } \\
\text { the research. }\end{array}$ \\
\hline Dissemination & $\begin{array}{l}\text { Identify communication channels in } \\
\text { the medical institution to disseminate } \\
\text { information about the diabetes } \\
\text { education program. }\end{array}$ \\
\hline Adoption - & $\begin{array}{l}\text { Communication channels promote the } \\
\text { program and employees schedule } \\
\text { appointments for the class or an } \\
\text { education visit as "early adopters". } \\
\text { Those channels which do not promote } \\
\text { the program or employees who do not } \\
\text { attend are "laggards". }\end{array}$ \\
\hline Implementation- & $\begin{array}{l}\text { Employees participate in the } \\
\text { education program, have A1C } \\
\text { checked, provide information about } \\
\text { days absent and ER/hospital visits, } \\
\text { choose a self-management goal, and } \\
\text { evaluate education. }\end{array}$ \\
\hline Maintenance & $\begin{array}{l}\text { Evaluation of the outcomes of } \mathrm{A} 1 \mathrm{C} \text {, } \\
\text { days absent, ER/hospital visits, } \\
\text { attainment of self-management goal, } \\
\text { and participants satisfaction. Review } \\
\text { program, barriers, consider changes } \\
\text { and implications. }\end{array}$ \\
\hline
\end{tabular}

Figure 1. Steps in the Diffusion of Innovations model (Rogers, 1995) applied to the worksite diabetes education program. 


\section{Review of the Literature}

\section{Background}

Controlling diabetes is a challenge. For decades after the discovery of insulin, people survived with diabetes, but then suffered and succumbed to microvascular complications of retinopathy, neuropathy, and nephropathy (Diabetes Control and Complications Trial, 1993). Intensive management through use of multiple daily injections or an insulin pump, multiple daily glucose checks, and extensive education was believed to show reduction in complications, but until 1993, no significant study had demonstrated that outcome. The Diabetes Control and Complications Trial (DCCT) Research Group published evidence from a randomized control trial demonstrating that intensive management of type 1 diabetes reduced complications as compared to conventional therapy which used one to two injections per day, single daily glucose check, and basic diabetes education. Findings included reduction of retinopathy by $76 \%$, nephropathy by $44 \%$ and neuropathy by $69 \%$ after six and one-half years of participation in the study (DCCT, 1993). Patient education and management by nurses were important components of the intensively managed group.

Following the results of the DCCT, the United Kingdom Prospective Diabetes Study (UKPDS) found benefits of intensive management as compared to conventional therapy for patients with type 2 diabetes (ADA, 2002). The sample of 5,102 patients entered the study with a median A1C of $9.1 \%$. After being followed for an average of ten years, the treatment group achieved a median $\mathrm{A} 1 \mathrm{C}$ of $7.0 \%$, while the control group achieved a median $\mathrm{A} 1 \mathrm{C}$ of $7.9 \%$. Lowering $\mathrm{A} 1 \mathrm{C}$ in the treatment group significantly reduced the incidence of microvascular complications by $25 \%$. 
Control of diabetes symptoms is dependent upon proper management and medication regulation. Uncontrolled diabetes leads to symptoms of fatigue, lack of concentration and coordination, hunger, thirst, increased urination, poor vision, and increased risk of infection (ADA, 2012). Any of these symptoms can impair function and ability to work. Sylvia, Weiner, Nolan, Han, Brancati, and White (2012) studied impairment of work ability by examining the prevalence of work limitations and the relationship to morbidity burden (severity of illness) in employees with diabetes at a large medical institution. Work limitations were defined as the functional limitations that restricted the person's ability to perform work responsibilities and potentially lead to work loss and disability. The study found the higher the morbidity burden, the more prevalent the impairment of work ability.

The ADA's (2010) position statement holds that any person with diabetes should be eligible for employment. However, high morbidity burden has the potential to be a barrier to attaining and maintaining employment. To achieve the employment goal of the ADA, Sylvia et al. (2012) recommend that nurses assess and educate employees, and provide resources for supervisors, coworkers, and administrative staff who support employees with diabetes. Further research is needed to examine the efficacy of diabetes self-management education (DSME) in community settings such as the worksite (United States Community Preventive Services Task Force, 2002).

To examine the literature concerning worksite diabetes education, databases including the Cochrane Library, OVID Medline, and CINAHL were searched for relevant articles from the year 2000 to the present, in English language, and in adults 18 years and older. Key words including employee education, diabetes, employee diabetes 
education, absenteeism, A1C, and hospitalization were utilized. To identify literature on behavioral outcomes of worksite employee education, the key word AADE-7 ${ }^{\mathrm{TM}}$, for the American Association of Diabetes Educators (AADE) seven self-care behaviors framework was used as well. Forty-three articles were identified. Twenty-five articles were excluded because they referred to pediatric interventions, involved school education programs, or a hospital-based patient education program for discharge or inpatient education. The website for the Agency for Healthcare Quality and Research was also reviewed for any worksite education initiatives for employees with diabetes. A report of one initiative was found. Thus, a total of 18 articles and one report were included as they contained findings concerning the relationship between diabetes, cost, and productivity, as well as worksite education initiatives that aim to decrease absenteeism, hospital visits, and/or levels of A1C. A table summarizing the identified literature can be found in Appendix A.

No literature was found on worksite education and measurement of selfmanagement behaviors. Further, no study used a theoretical framework. Of the four identified studies on worksite diabetes education, the majority of participants in two studies were Caucasian males and in the other two studies, Caucasian females, despite the fact that risk of diagnosed diabetes is higher in other ethnic groups (Boles, Pelletier, and Lynch, 2004). In 2009, compared with non-Hispanic white adults, the risk of a diagnosis of diabetes was $18 \%$ higher among Asian Americans, $66 \%$ higher among Hispanics/Latinos, and 77\% higher among non-Hispanic blacks (National Diabetes Information Clearing House, 2011). Eleven of the 18 articles explored the relationship between diabetes, levels of $\mathrm{A} 1 \mathrm{C}$, and productivity including presenteeism and 
absenteeism. The remaining seven articles reported outcomes of worksite education programs with four education programs specifically for people with diabetes (Burton \& Connerty, 2002; Carloti, Lavigne, Stone, Tortoretti, \& Chiverton, 2001; Thomas \& Miceli, 2006; Wolf, Siadaty, Crowther, Nadler, Wagner, Cavalieri, Elward, \& Bovbjerg, 2009).

\section{Examining the relationship of diabetes to productivity}

In order to prioritize education initiatives, it is important to understand diabetes influence on the productivity of various populations. Using data from the National Health Interview Survey and the U. S. Census Bureau, Tunceli, Zeng, Haviv, and Williams (2009), reported a relationship between the presence of diabetes and absenteeism, especially among males aged 20-44 years. The authors projected diabetes-related losses of complete and partial work disability through 2050. Based on current trends, their projections indicate that there will be an increase from 845,000 people not working because of diabetes in 2010 to 1.46 million people in 2050. The authors also conclude that there will be an increase in the number of people who have work limitations from 456,000 people in 2010 to 780,000 people in 2050 .

Three studies that examined work limitations and health reported that diabetes is correlated with a risk of decreased productivity or presenteeism and increased absenteeism (Boles, et al., 2004; Druss, Marchu, Olfson, Tanielian, Elinson, \& Pincus, 2002; Sylvia et al., 2012). Sylvia, et al. (2012) reported work limitations increased with higher levels of illness burden in diabetes. Boles, et al. (2004) found people with diabetes were most at risk for the productivity problems of absenteeism and presenteeism when compared with people suffering from other chronic diseases. 
Similarly, Druss et al. (2002) examined cost data from the Medical Expenditure Panel Survey (MEPS) which revealed diabetes was one of the top three chronic conditions for burden of work loss costs.

Four other studies examined the relationship between number of absences and diagnosis of diabetes (Skerjanc, 2001; Kivimaki, Vahtera, Pentti, Virtanen, Elovainio, \& Hemingway, 2007; Lavigne, Phelps, Mashlin, and Ledar 2003; and Tunceli, Bradley, Lafaa, Plandevall, Divine, Goodman, and Vijan 2007). Analysis of employee data by Tunceli et al. (2007) showed diabetes diagnosis and poor glycemic control were related to increased absenteeism. Skerjanc (2001) also reported people with diabetes had illnesses of a longer duration than those without diabetes. This finding was significant in males 31 to 40 years old. In another study of 472 subjects from a New York corporation, a diagnosis of diabetes was correlated with reduced self-reported productivity (Lavigne et al., 2003). The authors found no significant differences in absenteeism between people with or without diabetes. However, they noted a decrease in work efficiency for every year a person has diabetes. Kivimaki et al. (2007) conducted a record review of physician-certified illness of greater than three days and reported that people with a diagnosis of diabetes had a 2.15 fold increase in the rate of absence when compared to people without diabetes.

Two studies examined whether absenteeism in obese people was related to diabetes. Crawley et al. (2008) reviewed data from MEPS and found diabetes is strongly predictive of absenteeism among obese and morbidly obese people. The authors recommended that employers support obesity and diabetes prevention efforts. 
Rodbard et al. (2009) investigated work, social and family life disruption including work impairment and examined the relationship between diabetes, obesity, and work productivity. The authors used a stratified random sample from survey data of 200,000 heads of household in the U.S, $25 \%$ whom had diabetes. Diabetes and obesity were independent predictors of overall impairment including work absence. Younger women of lower socioeconomic status exhibited $44 \%$ greater impairment than men.

Oral diabetes medications have the potential to increase presenteeism and absenteeism because of side-effects and tolerability issues. DiBonaventura, Link, Pollack, Wagner, and Williams (2011) emailed potential participants for their study from a national internet-based Health and Wellness Survey. The investigators found that the majority of people in this convenience sample of people with diabetes reported having problems with their oral medication. As tolerability problems occurred, no significant increase was seen in absenteeism, but impairment of work activity in the form of presenteeism increased.

The previous eleven articles describe the problem of productivity in employees with diabetes. Lower productivity can come in either or both presenteeism and absenteeism. Researches seek to find the relationship between glycemic control and productivity. Studies may recommend further investigation to identify employees with diabetes who are most likely to have lowered productivity (Burton \& Connerty, 2002; Lavigne, et al., 2003). Other studies often recommend interventions to help improve the employees' health (Boles et al., 2004; Crawley et al., 2008; DiBonaventura et al., 2011; Druss et al., 2001; Sylvia et al., 2012; Tunceli et al., 2009). Understanding that some 
employees are more at risk can lead to investigation of interventions to help the employees.

\section{Health education at the worksite}

Studies on the relationship between diabetes and work productivity impairment indicate that employers could support initiatives to help lessen the disease burden of diabetes on the employees and possibly reduce productivity costs, health care costs, and attendance problems (Boles et al., 2004; Crawley et al., 2008; DiBonaventura et al., 2011; Druss et al., 2001; Sylvia et al., 2012; Tunceli et al., 2009). There are documented relationships between diabetes, glycemic control, absenteeism and presenteeism (Boles et al., 2004; Crawley et al., 2008; Kivimaki et al., 2007; Lavigne et al., 2003; Sylvia et al., 2011; Tuceli et al., 2007). Further, there is evidence that worksite health education can increase health promotion, decrease healthcare costs, improves work productivity and positively impacts the problems related to diabetes (Aldana, Merrill, Price, Hardy, \& Hager, 2005; Cancelliere, Cassidy, Ammendolia, \& Cote, 2011). Studies of health education at the worksite include assessments of employee's preferences and needs, evaluations of cost savings, and rates in presenteeism and absenteeism (Cancelliere et al., 2011).

Employers need to see evidence of cost savings and improved productivity in order to feel it is valuable to invest in health promotion and disease management programs (Pelletier, 2011). One study and two review articles examined health education programs at the worksite (Aldana et al., 2005, Canceliere, Cassidy, Ammendolia, \& Cote, 2011; Pelletier, 2011). In a study employees of a school district were invited to participate in a wellness program for up to two years (Aldana et 
al.,2005). The purpose of the study was to evaluate whether the program decreased healthcare costs and absenteeism. Data was examined during the study and continued after the wellness program ended. At the five year mark, there were minimal differences in healthcare costs between participants and nonparticipants, but reduction of absenteeism was statistically significant. Analysis after five years began to show a reduction in healthcare costs.

In one review article, Pelletier (2011) examined 27 worksite health promotion and disease management programs for a variety of diseases such as hypertension, obesity, diabetes, and lupus. They found that help for employees to reduce weight, $\mathrm{A} 1 \mathrm{C}$, and presenteeism is cost effective. The author noted seven of the studies were randomized controlled trials and recommended more studies of this type. Given the current evidence, Pelletier asserts that employers should not ask whether worksite programs should be implemented, but "rather how such programs should be designed, implemented, and evaluated to achieve optimal clinical and cost-effectiveness" (p.1329).

A second review examined 14 studies of worksite health promotion including five randomized controlled trials (Canceliere, Cassidy, Ammendolia, \& Cote, 2011). The authors concluded that more research is needed, but preliminary findings showed that worksite health promotion programs could improve presenteeism. Programs with the most significant results had a supportive workplace culture in which employees felt comfortable and were encouraged to participate in worksite health promotion, had leadership from supervisors and owners to value the health promotion, availability of health risk screening, and individually tailored programs. 


\section{Health education at the worksite specifically for employees with diabetes}

Four studies specifically examined worksite education for people with diabetes (Burton \& Connerty, 2002; Carloti, Lavigne, Stone, Tortoretti, \& Chiverton, 2001; Thomas \& Miceli, 2006; Wolf, Siadaty, Crowther, Nadler, Wagner, Cavalieri, Elward, \& Bovbjerg, 2009). Three of the four worksite diabetes education studies measured reduction in $\mathrm{A} 1 \mathrm{C}$ and the fourth examined employees' perceptions of the worksite program. In two of the studies, A1C showed significant reduction at three and six months (Burton \& Connerty, 2002; Wolf et al. 2009).

One of the worksite diabetes education studies that demonstrated a reduction in A1C was a randomized controlled trial with 147 employees, majority of whom were white females, who received usual treatment or diabetes education provided by registered dietitians acting as case managers over a 12 month period (Wolf et al. 2009). The dietitians provided individual or group education and acted as resources to employees in the health plan. The outcome was a statistically significant reduction in weight, $\mathrm{A} 1 \mathrm{C}$, and amount of missed work for the treatment group. Results for absenteeism were significant at four months.

The second study with results showing reduction in $\mathrm{A} 1 \mathrm{C}$ evaluated 53 employees who were also mainly white females with diabetes at a banking institution. A certified diabetes educator (CDE) delivered education modules to the employees at work (Burton \& Connerty, 2002). Levels of A1C were significantly reduced three and six months after the education. The investigators recommended further study of productivity, identification of employees with the highest risk from their disease, and program promotion to encourage more employees to participate. 
The third study which examined A1C had 347 employees, the majority white males, with diabetes and/or hypertension at Lockheed Martin plants in Georgia and Mississippi (Thomas \& Miceli, 2006) . The study placed employees in a "Know Your Health" program or usual care and found at six months no significant difference in A1C. The authors attributed the lack of significant change in A1C to the small number of participants (24 had only diabetes, 91 had a dual diagnosis) and short duration of the follow-up (six months), but blood pressure was significantly lowered in the intervention group. The authors concluded the study should be repeated with a larger number of employees followed for a longer period of time.

One worksite study by Carloti et al. (2001) did not examine A1C but rather looked at employees' perceptions of the program. Advanced practice nurses delivered education and care to 54 employees at worksite offices based on recommendation by their own primary care providers (Carloti et al., 2001). Employees with diabetes stated after they attended worksite education, they felt they had better knowledge and control of their disease.

The Agency for Healthcare Research and Quality (2009) reported on an additional worksite diabetes education program that was implemented in 2005 at three Chrysler Corporation plants. The 14-month innovation demonstrated the ability of a diabetes education program to decrease $\mathrm{A} 1 \mathrm{C}$ and absenteeism due to diabetes related illness. CDEs who were nurses, nutritionists, or pharmacists conducted either group or one-on-one sessions with the employees based on their preference. The educational sessions focused on employees' concerns and setting goals for management of diabetes including diet, exercise, and medications. Depending on the site, employees 
received group sessions before or after a shift, one-on-one sessions that they could attend during work, or a combination of both. Due to economic difficulties and the closure of one Chrysler plant, the number of participants $(n=125)$ was lower than originally anticipated. Results included an increase in knowledge of diabetes management as measured by a pre and post-test, a reduction in cholesterol, $\mathrm{A} 1 \mathrm{C}$, and a $50 \%$ reduction in absenteeism.

\section{Summary of the literature}

The review of the literature reveals there are more studies about the impact of diabetes on employee work productivity than about worksite diabetes education interventions. From the available literature included in this review it is possible to identify a number of key characteristics that can be considered best practices as well as shortcomings which can serve to inform programmers and policy makers. Best practices include tailoring education to the employee (Cancelliere et al. 2011), bringing diabetes education to the worksite (Burton \& Connerty, 2002; Carloti, et al., 2001; Thomas \& Miceli, 2006; Wolf et al., 2009), and evaluating outcomes such as absenteeism and A1C. To succeed in obtaining the Healthy People 2020 goal of educating more people with diabetes (HealthyPeople.gov, 2012), more programs involving nurses and CDEs should be designed and piloted based upon this available evidence.

Shortcomings identified were the presence of studies to examine the relationship of diabetes and productivity, but fewer studies examined worksite diabetes education interventions. Worksite diabetes education programs are often implemented in populations lacking in diversity and are therefore not designed and evaluated with 
attention to cultural differences, learning needs, and levels of risk. They suffer from an underutilization of theoretical frameworks that could enhance understanding of the complexities of diabetes education and management and inform the development and implementation of intervention strategies. Studies of these programs are typically conducted through surveys, analysis of existing data, and pre and post-test design interventions not randomized controlled trials. The majority of programs, such as the Chrysler initiative presented by the AHRQ (2009), measure changes in participant selfreported knowledge of diabetes, but did not measure attainment of the employee selfmanagement behavioral goals. Also, none of the worksite diabetes education programs evaluate the impact of the program on health care utilization and costs, such as emergency room visits and hospitalizations despite the fact that increased healthcare costs occur in people with a diagnosis of diabetes (ADA, 2008; Druss et al., 2001; Sylvia et al., 2012).

The DOI Theory (Rogers, 1995) provides a lens through which the key characteristics of a successful worksite diabetes education program can be viewed. First, program development has to begin with a needs assessment to ensure planning occurs with attention to the attributes which will potentially help it succeed. Participants need to find the program practical, an improvement over any current method of learning, affordable, and understandable. Before implementation, both employees and employers must come to understand how they can benefit from worksite diabetes education. For example, employers should learn that they stand to gain from successful outcomes via cost-savings and improved productivity. Further, when the program is implemented as a pilot, it must be evaluated and found to have trialability. The program should also be 
flexible and modifiable for future educational initiatives in a variety of settings in order to be sustainable. As noted in the review by Cancelliere et al. (2011), individually tailored education programs were the most successful.

Deficits in the literature include the lack of use of theoretical framework and lack of diversity in the populations studied. Diabetes education programs can be designed and evaluated with attention to cultural differences, learning needs, and attempting to engage those most at risk. Through assessment, planning, and following the process of a theoretical framework, the goal of worksite diabetes education to help employees attain self-management goals, improve $\mathrm{A} 1 \mathrm{C}$, reduce absenteeism, and minimize hospital/emergency department visits can become a reality.

\section{Methods}

\section{Purpose}

This project implemented a diabetes education program at a large urban medical center with a sample of employees diagnosed with type one and type two diabetes. The purpose of the study was to evaluate outcomes of worksite diabetes education for employees with diabetes who participated in the education program.

\section{Research Question}

What is the outcome of worksite diabetes education on $\mathrm{A} 1 \mathrm{C}$, days absent from work, visits to the emergency room/hospital, participants' self-management goals, and participants' satisfaction with the education?

\section{Study design}

The study was a quasi-experimental pre-test posttest design to examine the effects of a worksite diabetes education program on participating employees in a large urban medical institution. Outcomes included A1C, number of reported days absent 
from work, number of reported visits to the emergency room or hospital, selfmanagement goal attainment, and participant satisfaction. Participant recruitment, consent process, and program delivery occurred over a 10 week period from September 23 until November 25, 2013. Data were collected at baseline and three months after the diabetes education.

\section{Setting}

The site of the program was a large urban medical institution which is the largest private employer in the city. In 2010,33,618 regular employees and 6,050 student employees were working for the institution (Johns Hopkins University, 2010). The medical institution has a Diabetes Center in the centrally located outpatient center. The Center serves to evaluate, educate, and manage patients with diabetes with a staff of five endocrinologists and fellows, four CDEs; three masters'-prepared nurse practitioners, and one master's-prepared nutritionist. The center has been in existence since 1984 and received accreditation for its diabetes education program from the American Diabetes Association (ADA).

The Diabetes Center's education program is run by the CDEs. Group education classes and individual appointments have been available for over 10 years. However there have been no explicit efforts to increase employee awareness and participation in the diabetes programs and no evaluation of outcomes for the few employees who did participate in the Diabetes Center education program. During 2012, 226 people participated in education at the Diabetes Center, but only seven were employees. The internal medicine clinic at the medical institution made the majority of referrals to the program. 
The Diabetes Center can accommodate people with special needs. Print augmentation and sign language interpreters are available for people with visual and hearing deficits. The center is accessible to wheelchairs and other ambulation assistive devices. Interpreters are available for 25 different languages and health care providers and CDEs practice sensitivity to cultural diversity. The material used for patient information such as dietary guidelines are available for various cultures including information for religious celebrations, holiday foods, and managing diabetes during religious fasting. The education program at the Diabetes Center currently serves people who are white/Caucasian, black/African-American, Hispanic, Asian, Middle Eastern, and Asian Pacific Islander (from Johns Hopkins Comprehensive Diabetes Center quarterly data, April, 2012).

\section{Sample}

Adults 18 years of age or older, currently employed by the medical institution who had an established diagnosis for three months or more with either type 1 or type 2 diabetes were eligible to participate in the study. The three months criteria was picked to have an accurate reflection of control pre-education because the $\mathrm{A} 1 \mathrm{C}$ is a measure of diabetes control over a three month time period (Higgins, 2012). Potential participants had to speak English or another language with available interpreter services. Participants had to be medically stable. Those who were excluded from participation were children or family members of employees and pregnant women. The temporal nature of pregnancy may increase the need for intensive monitoring, cause rapid fluctuations in glucose, and problems other than diabetes which necessitate absenteeism and hospitalization. Also excluded were employees with secondary 
diabetes. For example employees with diabetes due to cystic fibrosis, chronic steroid use, cancer treatment, or pancreatectomy were not eligible for participation.

\section{Sample size calculation.}

Power was determined for statistical significance. Power is the ability to state with a given level of confidence that differences between the means in the sample before and after intervention are significant (Cohen, 1992). The confidence level was set at $95 \%$ with $\alpha=.05$ for a two-tailed study. The effect size was medium at 0.5 meaning the difference in the means that could be detected was one half standard deviation. Referring to Cohen's tables for power analysis for sample size for t-test of dependent means, the size needed for the sample was 64 people (Cohen, 1992). In an examination of the Diabetes Center's 2012 data after the education, approximately $10 \%$ of patients did not return for a follow-up visit. Accounting for $10 \%$ attrition, the goal sample size in order to detect a statistical significant difference is 70 people.

\section{Definition of terms and measures}

Employees with diabetes included any employee at the medical center who was diagnosed with either type 1 or type 2 diabetes at least three months prior to the education. $A 1 C$ is the laboratory blood analysis of the hemoglobin molecule to detect hemoglobin $\mathrm{A} 1 \mathrm{C}$ which is related to the glucose concentration around the red blood cell during its 120 day lifespan (Higgins, 2012). A1C is a physiologic indicator of glucose control done every three months. As is protocol for the center's established education program, when the employee arrived for the education, records of $\mathrm{A} 1 \mathrm{C}$ within three months of the education date or a new lab result of $\mathrm{A} 1 \mathrm{C}$ was obtained to establish baseline. A1Cs from accredited laboratory sources were accepted. A1Cs reported by 
the patient and not verified by lab report or provider notes were not accepted. A1C was again obtained at the three month follow-up visit.

Work absenteeism is the number of self-reported days the employee has been absent from work during three months prior to the education and three months after the education. At the initial education visit and at the three month follow-up, the participant completed an intake form asking about the number of days absent from work during the preceding three months (see Appendix C).

Emergency room/hospital visits is the self-reported number of visits to the emergency room or hospital for any cause during the three months before the education intervention and three months after. The number of self-reported emergency room/hospital visits made by participants was also obtained from the intake form (see Appendix C).

A self-management goal is related to one of the seven self-care behaviors from the American Association of Diabetes Educators-7 (AADE-7 ${ }^{\mathrm{TM}}$ ) (AADE, 2013). The selfcare behaviors are: (1) healthy eating, (2) physical activity, (3) monitoring, (4) medication management, (5) problem solving, (6) risk reduction, and (7) healthy coping/stress management (Peyrot, Peeples, Tomky, Charron-Prochownik, \& Weaver, 2007). In any ADA-accredited education program, participants must choose to focus on a self-management goal based on one of $A A D E-7^{T M}(A D A, 2012)$. During the education class or visit with the CDE at the Diabetes Center, participants were asked to choose one self-management goal. At the three month follow-up visit, the participant expressed where he or she was in goal attainment using the "Behavioral Score Dashboard" 
(AADE, 2013) in which the participant rates progress towards the goal in categories of percentages. The scale is as follows: $1(0 \%)=$ no progress; $2(25 \%)=$ making changes with minor setback(s); $3(50 \%)=$ changes becoming habits; $4(75 \%)=$ perceived health improvement; $5(100 \%)=$ lab results indicate improvement (see Appendix B). For ADA accreditation, the Diabetes Center set the standard that one half of the participants in the diabetes education program will achieve a $3(50 \%)$ progress towards their selfmanagement goals at the three month follow-up visit (AADE, 2011).

Participant satisfaction with the program was based on participant responses to the anonymous evaluation given at the end of the educational intervention (see Appendix C). Reflecting ADA program standards, participants were asked to complete an anonymous evaluation of the educational intervention that contained questions about whether he or she found the program helpful, what he or she would change about the education program, and whether the educator was effective. Using a Likert scale of 1-5 (1 equals "strongly disagree" and 5 equals "strongly agree." 1 represents the lowest and most negative impression on the scale, 3 represents an adequate impression, and 5 represents the highest and most positive impression), participants rated the following: this course lived up to my expectations; the content is relevant to my diabetes goals; the course activities stimulated my learning; the pace of this course is appropriate; the training facility was comfortable; the staff was professional and courteous; the information presented on diabetes management increased my awareness of how to live a healthier life; I would highly recommend this class to a friend. They also had opportunity to write in answers to questions about what improvements would they 
recommend and what is the most/least valuable about the education program. The final evaluation was a Likert scale asking whether they felt the CDE was effective.

Worksite diabetes education means diabetes education delivered by a CDE the Diabetes Center clinic at the medical institution where the employees work. The diabetes education is a single occurrence of class or individual visit with a CDE. Education covers topics from the curriculum used by the ADA accredited education program in the Diabetes Center.

$C D E$ is a certified diabetes educator who is a health care professional certified through qualifying criteria and an examination by the AADE and the National Certification Board for Diabetes Educators (NCBDE).

Participant measures include gender, age, ethnicity, type of diabetes, and years with the diagnosis of diabetes were obtained by report on the intake form. Categories for ethnicities were White, Black or African American, and Asian which is based on the standard United States Census race categories (United States Census Bureau, 2012).

\section{Procedures}

\section{Program description.}

The program followed the current model for diabetes education at the institution's Diabetes Center by offering both an individual and a group education program with a CDE. Therefore employees who contacted the Diabetes Center scheduling department selected and scheduled either a group class or an individual appointment. Both venues were offered to accommodate various needs related to timing of the session, complexity of the patient's situation, learning styles, desire for privacy, and other special needs. A letter one week prior and reminder call the day before the appointment was issued by the scheduling department to confirm the visit. The employee was asked to come 15 
minutes before the scheduled time of the class or appointment to receive an explanation of the study, and if willing to participate, sign the informed consent, as well as to complete a written intake form regularly used in the Diabetes Center (Appendix C).

At the beginning of the appointment or just before class started, the CDEs briefly reviewed the questions on the intake form (see Appendix C) with the participants and gave them an opportunity to ask questions about the program. The intake review took less than five minutes per participant and on class days, three to four CDEs were available for intake. If a participant were to arrive at the educational intervention in a medically unstable state or reveal information of concern such as uncontrolled depression or suicidal ideation, the CDEs were prepared to immediately refer the employee for care deemed most appropriate such as the emergency department, his or her provider, or employee health services.

The program's group education classes led by the CDEs were offered exclusively for employees in a three-hour class format with accommodation up to 15 employee participants per class. An individual appointment with the same CDEs who taught the classes was one hour long and held in a private office area. Participants could bring a support person to the individual appointment or group class. Diabetes education topics covered by the CDEs included understanding diabetes, nutrition, monitoring, medications, physical activity, and sick day management and were drawn from the Diabetes Center's ADA curriculum. The list of curriculum topics for diabetes education in either class or individual visit is in Appendix C.

Educational materials were presented by the CDE and reviewed with the employee(s) in the group class or at the individual appointment. The participants were 
encouraged to choose a self-management goal from one of the AADE-7 $7^{\mathrm{TM}}$ behavioral goals and write down steps to attain that goal on a "POWER" sheet used in the Diabetes Center (Appendix C). The POWER sheet was developed by Diabetes Center CDEs and the letters stand for Plan the goal, have Options to reach the goal, Write down the changes, Evaluate progress, and Reward yourself as you make progress. The educator assisted each participant individually with any problems completing the POWER sheet and answered questions both in the greater group or individually. Following ADA education standards (ADA, 2012), at the conclusion of the diabetes education class or visit with the CDE the participant had the opportunity to complete an anonymous evaluation to provide feedback about the program and the educator (see Appendix C).

After the participant attended an education class or individual visit, the participant made an appointment for a 30 minute follow-up with one of the CDEs three months after the initial education appointment. The Diabetes Center's scheduling office sent a reminder letter a week before the follow-up appointment and called the day before to confirm the appointment. At the three month follow-up visit, the CDE reviewed the self-management goals, and collected information about number of days absent and number of emergency room/hospital visits since program start. The employee's A1C was obtained, and the CDE provided any additional education needed.

\section{Sample recruitment.}

Following approval by the medical institution's Institutional Review Board (IRB) and University of Virginia IRB (see Appendix D), recruitment began through seven channels in order to reach potentially eligible employees. One recruitment channel was 
a contracted organization which promotes employee wellness at the institution. This wellness organization has access to the employees through an email distribution list and notifies about health fairs, seminars, and sends employees information about health topics. The wellness organization agreed to notify employees about the diabetes education program through an email message, its website, health fairs in the hospital, and at lunch time seminars as an add on to wellness topics such as weight loss and smoking cessation. A second channel was a flyer created with information about diabetes education for posting throughout the institution and also provided to the employee wellness organization for distribution (Appendix D).

A third channel of recruitment was through Care Management, a group of case managers from the employee health insurance plan that follows individual employees with diabetes. Through their routine phone calls to patients, Care Management provided employees the same information about the Diabetes Center education program as in the flyer. Finally, program information was channeled to the employees through four more channels of employee health, the internal medicine practices, the Diabetes Center, and the employee newspaper circulated by the institution.

\section{Protection of human subjects}

Employees were offered the education and attended voluntarily. Informed consent was obtained from each participant (see Appendix D). The employee could cancel the appointment or leave before the class or appointment was completed. Employees who sought care and education at the Diabetes Center, but did not want to be part of the study continued to schedule appointments or attend the usual educational program available to all patients. 
Privacy issues were carefully considered. The employees were given the choice when scheduling to have an individual appointment if he or she preferred not to be in a group class with fellow employees. The medical institution was not notified of employee participation or nonparticipation. The participant satisfaction evaluations were anonymous. For this program evaluation, a de-identified data set stripped of individual's names or any other personal information such as date of birth or address was created after the completion of the follow-up visits.

\section{Data Analysis}

For analyses, A1C, number of emergency room/hospital visits, and goal attainment were entered into the de-identified database. Descriptive statistics including the mean, standard deviation, frequency, and percent were conducted as applicable for the sample demographics, attainment of self-management goals, and satisfaction with education program. Dependent t-tests were used to compare pre and post educational program $\mathrm{A} 1 \mathrm{C}$, frequencies of absences, and number of emergency room visits and hospitalizations for the. Statistical analyses were conducted using Statistical Package for the Social Sciences (SPSS), version 21. All t-tests of pre and post-educational program were two-tailed, and significance was set at $\alpha=0.05$.

\section{Results}

The purpose of the study was to implement and evaluate outcomes of worksite diabetes education program for employees with diabetes at a large urban medical institution. The research question examined the outcomes of worksite education on A1C, days absent from work, visits to the emergency room/hospital, participants' selfmanagement goals, and participants' satisfaction with the education. Communication 
channels were developed to disseminate information about the program throughout the institution. Outcomes from the research question served as evaluation of the program.

\section{Outcomes}

\section{Institution adoption.}

Seven different communication channels provided employees information about the diabetes education program. Care Management, employee health, the employee newspaper, the Diabetes Center, the Internal Medicine clinics, and the posting of the flyer helped inform employees about the education program during the dissemination stage of the program. The wellness organization only showed partial adoption of the program and provided the flyer to employees at a screening fair, but did not notify employees through their website, nor did they send out an email to employees on its distribution list, or provide information to employees at the lunch time seminars. Care management actively disseminated the information to employees during their routine phone conversations. One participant who found out through Care Management, adopted the program by attending a diabetes education class and later encouraged two other employees to come to the program.

Another group in the institution needed to adopt the program. The scheduling department was responsible for scheduling the employees into diabetes education visits and classes. The times were set up in the scheduling computer, but there was a hold placed and employees could not be scheduled. The hold was discovered after two out of the four classes were held with minimal attendance and four employees emailed the investigator to state they had difficulty scheduling for the class. 


\section{Employee adoption.}

Twenty-seven employees were screened for the study. The final 20 employees were eligible or completed all parts of the program and evaluation. Four employees were excluded from the study. One employee was pregnant, one employee had pancreatic cancer and was on leave, one employee was leaving employment, and one employee received diabetes education in an appointment with the CDE, but was diagnosed with metastatic cancer a few days after the visit and was medically unstable. The other three excluded employees attended an education appointment, but did not have an A1C test, choose a self-management goal, or make a follow-up appointment.

Of the 20 participants who adopted the diabetes education program and completed the study, seven chose a group diabetes education class and 13 chose an individual diabetes education visit. The seven were able to attend three of the classes (two at one class, two at next class and three at the final class) despite the problem with the scheduling office. The flow of participants through the study in relation to $\mathrm{DOI}$ is shown in Figure 2. 


\section{Dissemination}

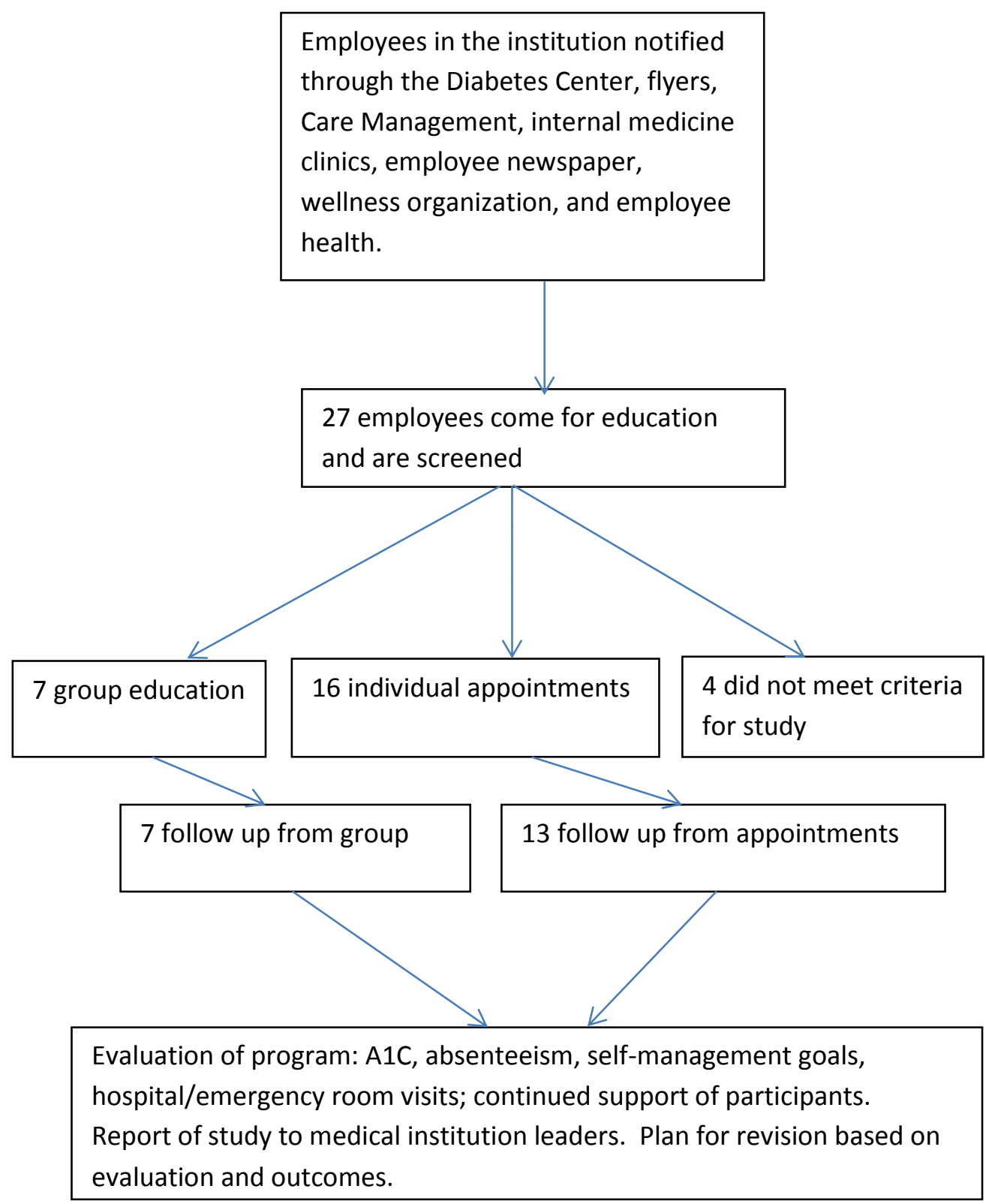

Figure 2. Flow of education program and relation to steps in Rogers (1995) Diffusion of Innovations. 
The final 20 participants in the study consisted of 14 females and six males. The majority were African-American ( $n=12 ; 60 \%)$, followed by Caucasian $(n=7 ; 40 \%)$, and Asian $(n=1 ; 5 \%)$. Nineteen had type 2 diabetes and one participant had type 1 diabetes. The average number of years since diagnosis was 7.7 (range: 1-23 years). Characteristics of the study sample are in Table 1. 
Table 1

Characteristics of the Study Population

\begin{tabular}{|c|c|c|}
\hline Variable & $\begin{array}{l}\text { Total Population } \\
(n=20)\end{array}$ & Percentage \\
\hline \multicolumn{3}{|l|}{ Sex } \\
\hline Male & 6 & 30 \\
\hline Female & 14 & 70 \\
\hline \multicolumn{3}{|l|}{$\begin{array}{l}\text { Age (years) } \\
\text { (mean=54) }\end{array}$} \\
\hline $18-40$ & 3 & 15 \\
\hline $41-60$ & 16 & 80 \\
\hline$>60$ & 1 & 5 \\
\hline \multicolumn{3}{|l|}{ Ethnicity } \\
\hline Black/African-American & 12 & 60 \\
\hline White & 7 & 35 \\
\hline Asian & 1 & 5 \\
\hline \multicolumn{3}{|l|}{ Type of Diabetes } \\
\hline Type 1 & 1 & 5 \\
\hline Type 2 & 19 & 95 \\
\hline \multicolumn{3}{|l|}{$\begin{array}{l}\text { Diabetes Diagnosis (years) } \\
\text { (mean=7.7) }\end{array}$} \\
\hline$<5$ & 8 & 40 \\
\hline $5-10$ & 6 & 30 \\
\hline $11-16$ & 5 & 25 \\
\hline$>16$ & 1 & 5 \\
\hline
\end{tabular}


A1C.

Initial $\mathrm{A} 1 \mathrm{C}$ within three months of coming to the education appointment or class had a mean of $8.5 \%(S D=1.80)$. Follow-up $A 1 C$ after the education had a mean of $7.5 \%(S D=1.3)$. There was a difference at the specified 0.05 significance level between pre and post values, $t(20)=2.887, d f=19, p=.009$. Seventy-five percent of participants reduced their A1C after the education. Six participants had an A1C less than the ADA goal of $7.0 \%$ prior to the education and nine participants had an $\mathrm{A} 1 \mathrm{C}$ less than $7.0 \%$ after the education. (Figure 3) 


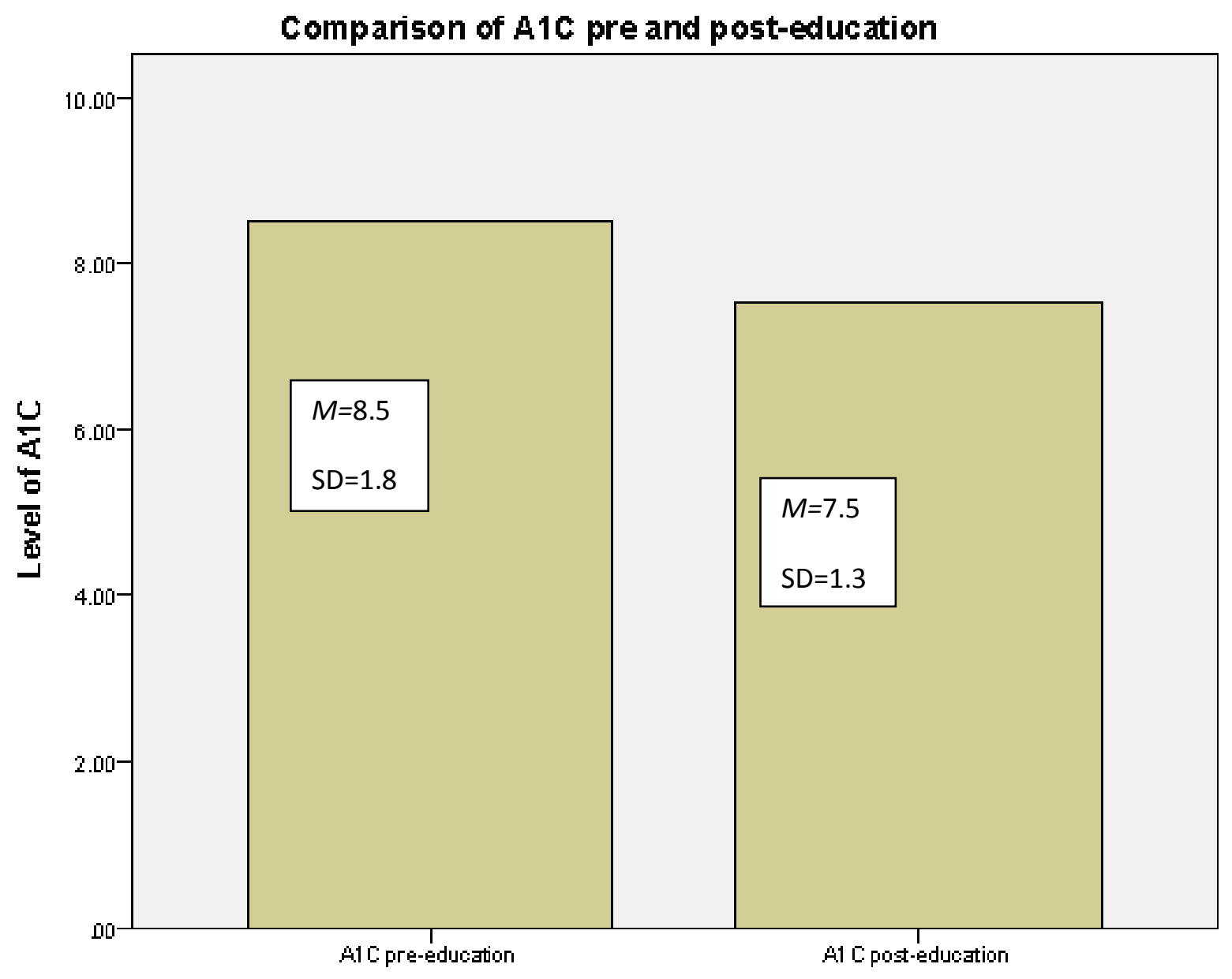

Figure 3. Comparison of A1C pre and post-education. 


\section{Days absent.}

The average number of days the participants reported absent in the three months preceding the diabetes education program was 1.25 days $(S D=3.43)$. After the education program, the average number of days reported absent in the preceding three months was lower at $0.65(S D=1.42)$. Dependent t-test results, $t(20)=.794, d f=19 . p$ $=.437$.

\section{Number of hospital/emergency room visits.}

The initial average reported hospitalization or emergency room visit during the three months prior to education was 0.25 visits $(S D=.44)$. Three months after education, the average reported hospitalization or emergency room visits was 0.20 visits $(S D=.41)$. Dependent t-test results, $t(20)=.370, d f=19, p=.716$.

\section{Attainment of a self-management goal.}

Participants were able to choose a self-management goal and were evaluated on progress towards that goal three months after education. The following goals were chosen: risk reduction $(n=8)$, healthy eating $(n=5)$, physical activity $(n=3)$, monitoring $(n=3)$, and taking medications $(n=1)$. Assessment of progress is determined by percentage towards the goal (AADE, 2013). Seventeen (85\%) of the participants attained a score of three $(50 \%)$ or greater in reaching a self-management goal. According to the Diabetes Center goal for ADA accreditation standards, at least one half of the participants in a diabetes education program need to reach a score of three (50\%) (AADE, 2011). See Table 2. 
Table 2

Behavioral Dashboard Score for Self-Management Goal Attainment (Peyrot et al., 2007)

Score (percent towards goal)

$\mathrm{n}$

$5(100) \quad$ lab results indicate improvement $\quad 8$

4 (75) perceived health improvement 5

3 (50) changes becoming habits 4

2 (25) making changes with minor setbacks 2

1 (0) no progress 1 


\section{Participant's satisfaction.}

Seventeen of the participants submitted anonymous education evaluations (Appendix C). All participants rated all categories as " 5 " (represents the highest and most positive impression) on a 1-5 Likert scale. Written comments included the class should be longer, provide snacks, make all diabetic employees do this, and all information is helpful.

\section{Discussion}

The majority of participants had improvements in A1C and showed progress in diabetes self-management goals. They also expressed a high rate of satisfaction with the education. Absenteeism trended downward and number of hospital/emergency room visits did not change. DOI helped to guide the study and also served to increase the understanding of how the institution and employees adopted the education program.

\section{Outcomes}

\section{Institution adoption.}

No diabetes education program specifically directed to employees existed prior to this worksite diabetes education program. Employee participation in the education program was crucial to its success. As more employees adopt the education program, they can influence others in the organization to attend the education as a norm in the social structure (Rogers, 1995). The communication channels are the way to disseminate the information. If the channels do not adopt the program, this can create a barrier to bringing employees to the program and seeing positive outcomes from the education program. Thomas and Miceli (2006) reported difficulty in seeing a difference in $\mathrm{A} 1 \mathrm{C}$ following an education for employees with diabetes or hypertension due to the 
small number of people with diabetes who participated. Not all channels or groups in an organization adopt the program as in the case of the wellness organization and the scheduling department. The education classes designated specifically for employees were a new type of class and scheduling something new may have been too complex. The scheduling department may have suggestions how they can schedule a new class without problems. To increase employee participation in the future, more communication channels will need to be explored such as through human resources and employee insurance plans. The strong relationships with communication channels that have been developed will need to be continued.

A1C.

Reduction of $\mathrm{A} 1 \mathrm{C}$ is critical to preventing long-term complications of diabetes as seen in the DCCT (1993) with type 1 diabetes and the UKPDS (ADA, 2002) with type 2 diabetes. In the UKPDS, for every one point reduction in A1C, the risk of microvascular complications reduced by $37 \%$. The initial average A1C for this group of participants with predominantly type 2 diabetes (95\%) in the worksite diabetes education program was $8.5 \%$. Three months after the education, participants' average A1C decreased to $7.5 \%$, equating to a risk reduction of $37 \%$. The reduction in $\mathrm{A} 1 \mathrm{C}$ over three months has clinical significance. A one point decrease in A1C is as good as or better than A1C decrease from the use of one oral diabetes medication (AHRQ, 2011). Oral medications can create tolerability problems for employees (DiBonaventura et al., 2011). Impairments from oral medications can increase presenteeism. If education can lower $\mathrm{A} 1 \mathrm{C}$ by the same amount as oral medication, employees may need less medication and be more productive. 
Short-term benefits of improved glucose control are the reduction in symptoms of diabetes of blurry vision, thirst, hunger, polyuria, increased infections, and fatigue. (ADA, 2002; DCCT, 1993). Similar to the worksite diabetes education program at the Diabetes Center, Burton and Connerty (2002) also found A1C reductions at three and six months after worksite education by CDEs at a banking institution. Lowering glucose reduces unpleasant symptoms and can improve how the employees feel and function. The participants were taught the meaning of the $\mathrm{A} 1 \mathrm{C}$ through the education program and made aware of the Diabetes Center education program as a resource in maintaining successful control.

\section{Days absent.}

The number of days absent trended downward. The Chrysler worksite diabetes education initiative by the AHRQ (2009) found a $50 \%$ reduction in the number of days absent over 14 months. Perhaps this pilot sample was too small and the time frame too short to see a statistically significant difference, but the trend indicates a reduction. A sustained improvement in $\mathrm{A} 1 \mathrm{C}$ greater than three months may be necessary to translate into improved health with less time away from work for illness. Wolf et al. (2009) was able to note a significant reduction in absenteeism at four months which was the earliest reported difference in absenteeism. In addition, the participants also had weight loss, reduced $\mathrm{A} 1 \mathrm{C}$, reduced medication use, and improved quality of life after participating in diabetes education.

Reasons for absenteeism may be complex. For example, one participant in the worksite diabetes education came in with an $\mathrm{A} 1 \mathrm{C}$ of $8.7 \%$ and had a concurrent problem with arthritis which was severe enough to require a knee replacement. Her 
surgery was delayed however, because her diabetes was not in control. Over the three months following education, she was able to lower her $\mathrm{A} 1 \mathrm{C}$ to $7.0 \%$ and now surgery will be planned necessitating a hospitalization and absence. Another participant and her primary care provider had attributed the participant's fatigue, edema, and shortness of breath to her obesity and diabetes. After attending an education appointment, the participant took her diabetes medications and improved her diet, lowering her $\mathrm{A} 1 \mathrm{C}$ from $7.6 \%$ to $6.8 \%$ and losing 23 pounds. As the diabetes was improving, she continued to note the fatigue and shortness of breath despite weight loss and home monitoring glucose at goal. Further medical work-up revealed left ventricular hypertrophy and early congestive heart failure. As a result, she missed three days of work for medical appointments during the three months following education, but is now treated and symptom free. Additionally, she is able to fully carry out the responsibilities of her position which included walking to various units in the institution. When she felt fatigue and shortness of breath, her duties had been reduced due to her increased level of presenteeism. For these two participants, absenteeism did not decrease, but quality of life increased and after improvement of diabetes and resolution of their medical problems, presenteeism will decrease.

Presenteeism or reduced productivity may be impacted quickly by diabetes education and related to the drop in A1C and improvement in diabetes symptoms. Boles et al. (2004) found that people with diabetes were more likely to have problems with presenteeism than people with other chronic illness and that presenteeism was a greater problem than absenteeism. Studies about diabetes and presenteeism recommend further investigation to identify employees with the most risk of lowered 
productivity (Burton et al., 2002; Lavigne et al., 2001). Continued study of participants in the worksite diabetes education program could include examination of presenteeism.

\section{Number of emergency room/hospital visits.}

The average number of hospital/emergency room visits before and after the education did not change. The group of participants in the education program had a small average of .25 days absent in the three months prior to the education and an average of .20 days absent following the education. The participants accessed the Diabetes Center for education and may be adept in accessing care reflected in low emergency room/hospital visits. As with number of days absent, the number of participants may have been too few and the length of time to see differences too short. A long-term prospective study with a much larger number of participants may be necessary to see a change in hospital/emergency room visits. The education program does cover self-care and how to manage sick-days which potentially improves participants' ability to know how to care for illness and when to properly access care before the illness becomes an emergency or needs hospitalization.

\section{Attainment of a self-management goal.}

Previous studies have not examined the outcome of worksite diabetes education on attainment of a self-management goal. The Chrysler initiative (AHRQ, 2009) encouraged employees to set self-management goals, but did not measure attainment. In the worksite program at the Diabetes Center, $85 \%$ of the participants showed marked progress towards a self-management goal meeting the ADA goal for the Diabetes Center's evaluation of education at three months post education. Behavior change to improve lifestyle is essential in diabetes self-management. The AADE asserts that the 
best way to impact behavior change in diabetes is through the use of behavior goals (AADE, 2013). Each education program chooses a level of goal expectation the participant should reach by three months after the education (AADE, 2011). Over one half of the participants attained at least $50 \%$ progress towards a self-management goal. The Diabetes Center set goal attainment at three months following education to be $50 \%$. Ideally, all people with diabetes who receive education can reach $100 \%$ success in goal attainment eventually, but the first step is progress towards that goal. Just as it is important to individualize education (Cancelliere et al., 2011), it is also important to individualize goals and attainment (AADE, 2013). The study implemented the education program for the employees with evaluation at three months with. The participants are now aware of the resources in the Diabetes Center and can continue to be followed after the study to fully attain self-management goals, learn more, and maintain glycemic control.

\section{Participant's satisfaction.}

On the voluntary education evaluation, all participants rated the quality of the education and the educator with a number " 5 " for "highest and most positive impression". They were able to include any written comments as well. Comments included the class should be longer, provide snacks, make all diabetic employees do this, and all information is helpful. Similar results were reported by Carloti (2001). Employees perceived they had better knowledge and control of diabetes after having education from advanced practice nurses. According to Rogers, "Success in securing the adoption of innovations by clients is positively related to the degree to which a diffusion program is compatible with clients' needs" (1995, p. 340). Based on the 
evaluation, it would appear that participants' needs are met. However, the evaluation may need to be more specific to the employee and include questions about topics such as convenience of the class or appointment with work and if the course content properly addressed challenges the employee faces dealing with diabetes and working.

In the literature review by Cancelliere et al. (2011), successful workplace health education programs had a culture and leadership supporting employee health. The education evaluation is anonymous making it a possible venue for employees to express how easy it was to be involved in worksite diabetes education. Other questions specific to employees in the institution could include how they found out about the program, how easy was it to attend (concern about missing work), and do they feel the institution supports their efforts to manage their diabetes.

\section{Following the Framework (see Figure 1)}

\section{Innovation development.}

The Diabetes Center education program had not been specifically targeted towards the education needs of the employees at the medical institution prior to this study. According to Sylvia et al.(2012), employees experience problems from reduced productivity and the implication is to have nurses play more of a role in the worksite with employees with diabetes, for example through education. The medical institution already had an education program in place at Diabetes Center, but was underutilized by employees. An additional step during the innovation phase could have been a more thorough assessment of why the Diabetes Center was underutilized by employees prior to the worksite diabetes education program. One thought was lack of awareness and need for dissemination of information about the education program. 


\section{Dissemination and adoption.}

During the dissemination phase of the initiative, employees found out about the worksite diabetes education program through the communication channels. According to Rogers' DOI theory (1995), some will be early adopters of a new innovation. Care Management was an early adopter in this case and recommended employees contact scheduling to set up an appointment with the Diabetes Center for education. The employee who attended one of the first classes in this program successfully recruited two of her coworkers to the program was also an early adopter. The wellness organization had the potential to reach a large number of employees, but did not disseminate information as they were only accustomed to promoting their internal education. The wellness organization would be placed in a category according to Rogers called "laggards". Their partial completion of the new outreach exemplifies a "laggard" who is not as proactive to adopt the innovation (Rogers, 1995).

Prior to this initiative, the scheduling department did not have requests to schedule special classes such as the employee education classes. As a new task, problems occurred with the ability to schedule patients into the classes. As a new initiative, the scheduling department could not accommodate a new pattern of scheduling. According to Rogers (1995, page 395), an innovation is modified to fit an organization, but the organization may have to accommodate the innovation. The process in place with scheduling may not have been able or ready to accommodate this new pattern of scheduling for a specific diabetes class. Despite the difficulty with scheduling, seven participants attended the classes. In the entire year of 2012, seven 
employees attended diabetes education program classes, equaling the number in the study recruited to the education classes over a 10 week period (From Johns Hopkins Comprehensive Diabetes Center annual data, 2012).

To increase the number of employees who are made aware of the education and able to schedule to attend a class, it may be beneficial to explore other methods of notification and other methods for scheduling. The contracted employee wellness organization has access and ability to do mass notification to employees, but did not follow through. Other groups within the institution have this same access to the employees and could be explored. During dissemination, it is important to have early adopters among the communication channels and groups in the organization who are essential to the process of the program.

\section{Implementation}

An innovation needs to be disseminated, adopted, and implemented to a wide part of the targeted population. If only one segment of the employee population found out about the program and could participate, success would be limited. The employees who came to the classes or appointments were comprised of African American ( $n=12$; $60 \%)$, Caucasian $(n=7 ; 35 \%)$, and Asian participants $(n=1 ; 5 \%)$. From US Census data (2012), the area surrounding the medical institution has a similar population comprised of African American (63.6\%), Caucasian (31.4\%), and Asian (2.5\%). The majority of participants were African American women. Although the population surrounding the medical institution is $4.4 \%$ Latino, no one of that ethnicity attended the program. In the US population, type 2 diabetes is the dominant type of diabetes and 
two common risk factors for diabetes include age over 45 years and African-American ethnicity. The study sample reflects this diabetes risk in the US population.

In previous studies, the majority of participants were white (Burton \& Connerty, 2002; Carloti et al., 2001; Thomas \& Miceli, 2006; Wolf et al., 2009). National survey data by the National Institute of Diabetes and Digestive and Kidney Diseases (NIDDK) for people over 20 years old reported that $7.1 \%$ of non-Hispanic whites, 8.4 percent of Asian Americans, 11.8 percent of Hispanics/ Latinos, and 12.6 percent of non-Hispanic blacks had diagnosed diabetes (National Diabetes Information Clearinghouse, 2011). In the current project, the participants were more representative of the increased African American population diagnosed with diabetes. Research has shown that just as people from different ethnicities are more at risk for developing diabetes, some ethnicities are more likely to suffer from microvascular complications, especially nephropathy (Bhalla, Zhao, Azar, Wang, Choi, Wong, Fortmann, \& Palaniappan, 2013). Ideally, an education program for employees with diabetes should be open to those most impacted by the disease through assessment of the populations' education needs, educators with understanding of different cultures, and individualization of the education (Haas, Marynuik, Beck, Cox, Duker, \& Edwards, 2014).

Implementation of the education program had minimal difficulties, with the exception of the class scheduling issues. This is most likely because education program was already in existence at the Diabetes Center and has a process for educating participants in a class or individual appointment with a CDE. Classes had few participants possibly from the scheduling difficulties, but because of the small size, offered attention and interaction with the participants. Further successful adoption and 
implementation of the program is dependent on employee attendance and meeting the education needs of the participants. Since the diabetes center is located at the medical institution campus, classes and appointments could be perceived as convenient for the employees. The program offers both individual visits and the group education to allow employees to have the privacy of an individual appointment. Implementation could be more difficult if hours for education expanded to reach employees who wanted to come just before, during, or after a night shift due to need for staff and changing the CDE's hours.

\section{Maintenance.}

Evaluation provided by the participants can be highly valuable in maintaining or modifying the current program for sustainability (Rogers, 1995). Changes to the written evaluation could help structure worksite diabetes education in the future. The evaluation was general asking the participant to rate satisfaction with the CDE, the education, or would he or she recommend the class to a friend. A new evaluation could contain questions specific to accessing education as an employee with diabetes.

Participants had improvements three months after the education. Continued evaluation of the participants could help determine lasting impact from the education. The participants may need regular follow-up at the Diabetes Center to maintain and continue improvements in $\mathrm{A} 1 \mathrm{C}$ and attainment of self-management goals.

The supportive groups within the institution such as Care Management need feedback about how their role helped to get employees to the education and how the employees improved. The positive results need to be reported to leaders in employee health, human resources, and to the employee insurance plan. Knowledge and use of 
the Diabetes Center education program enables groups involved in employee health to have a worksite resource for employees with diabetes.

\section{Limitations}

The study functioned as a pilot to determine feasibility of a larger-scale employee worksite education program, but had limitations including a small group of participants, a short period of evaluation, and no comparison group. No initial surveys were done to determine why employees had previous sparse attendance at the Diabetes Center classes or how employees perceived their educational needs. The small sample of employees limited the ability to determine differences in characteristics of employees who chose group versus individual education. In addition, differences in outcomes between group and individual education could not be assessed.

In the study, class scheduling difficulties may have limited the number of participants in the classes. Additionally, employees who attended the education program may have had to miss work to come to the appointment. Some employees may have work and personal barriers which would make attending a class or appointment difficult. The study was done at one setting with employees who voluntarily came to the Diabetes Center. Employees who chose to attend the program may bias results by being more motivated to improve their diabetes. Education was delivered through individual appointments and group classes through the Diabetes Center as is standard practice, but no other methods of education to reach employees were evaluated such as online education or written programs. Since the classes and appointments were during normal clinic day hours, some employees who work other shifts may not have participated. 


\section{Implications}

The study of worksite employee education has several implications including establishing this program at the medical institution, how to increase worksite diabetes worksite education for employees in other settings, the contribution to and need for more research, and the implications for nursing practice.

\section{Implications for the setting.}

The worksite diabetes education program was successful in the medical institution setting for delivering education to 20 participants, increasing the number of employees who attended a diabetes education class, and seeing positive changes in $\mathrm{A} 1 \mathrm{C}$ and attainment of a self-management goal. The communication channels in the institution can continue to encourage employees to seek diabetes education through the Diabetes Center. Further tracking of how many employees are educated at the Diabetes Center and how many from the study continue to come to the Diabetes Center will help to assess growth in the program. Intermittent evaluation of the program with attention to satisfaction, learning needs, and demographics can help with sustainability.

The program served employees of varying ethnicities representative of those who carry the most risk for diabetes and diabetes complication. People of varying ethnicities gave positive evaluations of the education they received. In a large institution with a varied population, it is important to have worksite diabetes education which is flexible to meet the needs of culturally diverse participants. Further evaluation of the education specific to cultural needs could be developed, such as modifying the nutrition curriculum to adapt to people of different cultures. Leaders from the 
community could be invited to speak at the classes to engage employees from their own neighborhoods.

On one evaluation, a participant commented "make all diabetic employees do this". While it would not be ideal to "make" an employee attend this program, increasing the availability of diabetes education for employees has the potential to be beneficial. Positive incentives can play a role in increasing the rate of adoption and the number of employees who attend the program (Rogers, 1995). Sylvia et al. (2012) used an incentive of a free calorie-counting book and session with a health coach to any employee who completed a study survey. Incentives are in place for employees at the medical institution. For example, employees who participate in Care Management do not have to pay any insurance copays for glucose testing supplies or generic diabetes medications. If the employee insurance plan sees the results of the worksite diabetes education program, perhaps they could eliminate the copay for the initial education visit at the Diabetes Center.

Institutional policy could ensure all employees be offered information about resources available to them, including diabetes education through the Diabetes Center on campus. Further communication within the institution such as discussions have begun with the human resources department to provide all new employees identified as having a diabetes diagnosis with information about the Diabetes Center. Additional changes could be made to allow people with diabetes to attend a diabetes education class or visit without using leave time. Burton and Connerty (2002) conducted diabetes education during lunches which were provided for the employees, while the Chrysler 
initiative (AHRQ, 2009) made it possible for employees to get away from work for an education session or had the CDE available immediately before or after a shift.

The employee worksite diabetes education program could serve as a model for other chronic illnesses in employees in the institution. Clinics such for conditions such as asthma, congestive heart failure, and preventive cardiology have advanced practice nurses (APNs) who could encourage employees to come to their clinics and provide education on self-management and prevention. APNs are successful in educating employees at the worksite (Carloti et al., 2001).

\section{Worksite diabetes education at other places of employment.}

The Diabetes Center is conveniently available at the medical institution, but not all medical institutions and very few other places of employment have CDE's. In addition, CDEs may be costly and difficult to find. Worksite diabetes education can be accomplished by bringing in nurses, nurses who are CDEs, APNs, and nutritionists as case managers (AHRQ, 2009; Burton \& Connerty, 2002; Carloti, et al., 2001; Thomas and Miceli, 2006; and Wolf et al., 2009). If a company has an employee health clinic, the nurses could receive training in diabetes education to be able to educate employees on site. If a clinic is not present, education could be delivered to employees through a web-based program, computer modules, written material, or videos. Resources in the community, such as diabetes support groups and local chapters of the ADA could be encouraged to partner with businesses and companies to educate and support employees. 


\section{Implications for research.}

The findings from this study of worksite diabetes contribute to the understanding about worksite diabetes education programs. More studies have been done on the relationship of diabetes to productivity and costs than studies about interventions to educate people with diabetes. In three months, differences are seen in A1C and participants are able to make progress in attaining a self-management goal. Worksite diabetes education studies should be conducted for a longer period of time to assess further attainment of self-management goals and whether improvements in $\mathrm{A} 1 \mathrm{C}$ are sustained. People with diabetes have been found to have a 2.15 fold increase in absences over other employees (Kivimaki et al., 2007). With a longer study and more participants, reductions in absences and number of emergency room/hospital visits may become statistically significant.

Additional study of the employees in the worksite diabetes education could be done. One employee reported a 23 pound weight loss in the three months following education. Weight, blood pressure, cholesterol, and abdominal circumference are just a few examples of related measures which could be examined. Also, study participants chose to attend an individual education visit or a group class. The study could examine the differences between employees in group versus individual education. The employees may differ and/or the outcomes may differ depending on which education they attended.

Previous worksite diabetes education studies were conducted with a majority of Caucasian employees (Burton \& Connerty, 2002; Carloti, et al., 2001; Thomas \& Miceli, 2006; Wolf et al., 2009). This study had a group comprised of African-Americans (60\%), 
Caucasians (35\%), and Asian (5\%) people. In a large urban medical institution where research studies are common and employees may be involved in conducting research, there may be a higher level of comfort to participate in a study than in other settings. Research needs to be done to examine how education in the worksite can attract and serve ethnically diverse populations since they are at the highest risk for diabetes (National Diabetes Information Clearinghouse, 2011).

More research needs to be done to discover the reasons why employees do or do not attend education. Before implementing an education program, employees could be surveyed and invited to focus groups to find out their perceptions of how a worksite diabetes education program could help them. The employees who participated in this study came voluntarily, reported satisfaction with the education, and had positive outcomes. They may have different characteristics than the employees who did not seek out the education program. Additionally, employees who attend worksite education programs may have supportive managers (Cancelliere et al., 2011).

\section{Nursing practice implications.}

Nurses and nurses who are CDEs are present in worksites and can direct employee education programs thus increasing access to care for people with diabetes. When a nurse is not present at the worksite, employers can consult nurses for their expertise in diabetes education to bring an education program to the employees whether it is through live interaction or other modes of education delivery. Investigating methods that are most effective for employees through evidence-based research is important to guide those initiatives. 
From knowledge gained carrying out the pilot initiative of worksite diabetes education, an opportunity exists for partnership between the PhD prepared nurse and the DNP prepared nurse to work together to improve worksite diabetes education. Per DNP Essential III: Clinical Scholarship and Analytical Methods for Evidence-Based Practice a role of the DNP is to "design, direct, and evaluate quality improvement methodologies to promote safe, timely, effective, efficient, equitable, and patientcentered care" (American Association of Colleges of Nursing, 2006). The DNP promotes diabetes worksite evaluation in a setting to increase access and meet the needs of the employees with diabetes. Program development and implementation could be based on and guided by research findings from the PhD nurse. The research implications from the worksite diabetes education program study could be structured by the $\mathrm{PhD}$ nurse to find the best practices and opportunity for generalization for use in other settings. Together, they can advance evidence-based care in the worksite for employees with diabetes.

\section{Conclusion}

With the ever increasing numbers of people with diabetes, the health care system faces an increasing need to improve the health and decrease the cost burden from diabetes. Efforts such as this program are needed to bring education to the employee at the worksite. The worksite diabetes education program provided a benefit where no other program existed for the employees at the large urban medical institution. The results showing a reduction in $\mathrm{A} 1 \mathrm{C}$ and progress towards a self-management goal need to be interpreted with caution and cannot be generalized outside the study group, but are encouraging and can be the basis for a continued program and further study. 
DOI provided a guide with steps that could be followed to institute change in both the institution and the participants in the education program. With future expansion of this education program or initiation of additional educational programs inside or outside the institution, DOI can be used as a guide both for sustainability of the current program and for developing much needed new programs in other employee settings. Nurses who are present in a variety of settings including the worksite with wide access to people with diabetes can use the framework to create education programs in their settings and impact the health of people with diabetes. 


\section{References}

Aldana, S.G., Merrill, R. M., Price, K., Hardy, A., and Hager, R. (2005). Financial impact of a comprehensive multisite workplace health promotion program. Journal of Preventive Medicine, 40, 131-137.

Agency for Healthcare Research and Quality AHRQ (2009). Diabetes Educators Provide Counseling at Worksites, Leading to Enhanced Knowledge, Improved Outcomes, and Reduced Absenteeism. Retrieved from: http://www.innovations. ahrq.gov/content.aspx?id=2392.

Agency for Healthcare Research and Quality AHRQ (2011). Oral Diabetes Medications for Adults With Type 2 Diabetes: An Update. Retrieved from: http://www.ahra.gov/news/newsletters/research-activities/may11/0511RA23.html American Association of Colleges of Nursing (2006). The Essentials of Doctoral Education for Advanced Nursing Practice. Retrieved from: http://www.aacn.nche.edu/publications/position/DNPEssentials.pdf. Accessed September, 2013.

American Association of Diabetes Educators (2013). AADE 7 Self-care Behaviors retrieved from: http://www.diabeteseducator.org/ProfessionalResources/AADE7/. American Association of Diabetes Educators (2013). Behavioral Score Dashboard. retrieved from: http://www.diabeteseducator.org/Members/BehaviorScore.html. 
American Association of Diabetes Educators (2011). Outcome measurement position statement retrieved from: http://www.diabeteseducator.org/export/sites/aade/_resources/pdf/research/Outc ome_Measurement_Position_Statement_2011.pdf.

American Diabetes Association. (2010). Diabetes and employment. Diabetes Care, 33, S1, S82-86.

American Diabetes Association. (2012). Economic costs of diabetes in the U.S. in 2012. Diabetes Care. 36(4):1033-46.

American Diabetes Association. (2002). Implications of the United Kingdom

Prospective Diabetes Study. Diabetes Care, 25 (1), S28-S32.

American Diabetes Association. (2012). Position statement: Standards of medical care in diabetes. Diabetes Care, 35(1), S1-S53.

American Diabetes Association (2013). Standards of medical care in diabetes. Diabetes Care, 36 (1), S11-S66.

Bhalla V., Zhao B., Azar KM., Wang EJ., Choi S., Wong EC., Fortmann SP., and Palaniappan LP. (2013). Racial/ethnic differences in the prevalence of proteinuric and nonproteinuric diabetic kidney disease. Diabetes Care, 36(5),:1215-21.

Boles, M., Pelletier, B., and Lynch, W. (2004). The relationship between health risks and work productivity. Journal of Occupational and Environmental Medicine, 46(7), 737-745

Burton, W. N. and Connerty, C. M. (2002). Worksite-based diabetes disease management program. Disease Management, 5(1), 1-8. 
Cancelliere, C., Cassidy, J. D., Ammendolia, C. and Côté, P. (2011). Are workplace health promotion programs effective at improving presenteeism in workers? BMC Public Health, 11:395.

Carloti, C. A., Lavigne, J. E., Stone, P., Tortoretti, D. M., and Chiverton, P. (2001). Work site disease management outcomes: Expanding the role of the APN. Outcomes Management for Nursing Practice, 5(4), 179-186.

Cawley, J., Rizzo, J. A., \& Haas, K. (2008). The association of diabetes with job absenteeism costs among obese and morbidly obese workers. Journal of Occupational \& Environmental Medicine, 50(5), 527-534.

Centers for Disease Control Diabetes ( 2011). Public Health Resource. Retrieved from: www.cdc.gov/diabetes/pubs/factsheets/atwork.htm.

Centers for Disease Control (2011). National Diabetes Fact Sheet. Retrieved from: http://www.cdc.gov/diabetes/pubs/pdf/ndfs 2011.pdf.

Cohen, J. (1992). A power primer. Psychological Bulletin, 112(1),155-159.

The Diabetes Control and Complications Trial Research Group (1993). The effect of intensive treatment of diabetes on the development and progression of long-term complications in insulin-dependent diabetes mellitus. The New England Journal of Medicine 329 (14), 977-986.

DiBonaventura, M., Link, C., Pollack, M. F., Wagner, J. S., \& Williams, S. A. (2011). The relationship between patient-reported tolerability issues with oral antidiabetic agents and work productivity among patients having type 2 diabetes. Journal of Occupational \& Environmental Medicine, 53(2), 204-210. 
Druss, B. G., Marcus, S. C., Olfson, M., Tanielian, T., Elinson, L., and Pincus, H.A. (2001). Comparing the national economic burden of five chronic conditions. Health Affairs, 20(6), 233-241.

Edberg, M. (2007). Essentials of Health Behavior: Social and Behavioral Theory in Public Health. Sudbury, MA: Jones \& Bartlett Learning.

Haas, L., Maryniuk, M., Beck, J., Cox, C., Duker, P., \& Edwards, L. (2014). National standards for diabetes self-management education and support. Diabetes Care, $37,1 S, 144-154$.

Hanson, R. L., Imperatore, G., Bennett, P. H., \& Knowler, W. C. (2002). Components of the "metabolic syndrome" and incidence of type 2 diabetes.

Diabetes, 51, 3120-3127.

Healthy People 2020 Topics and Objectives: Diabetes (updated 2012, September 6). Retrieved 9/12/2012 from: http://www.healthypeople.gov/2020/topicsobjectives2020/overview.aspx?topicid= 8.

Hunt, C. W. (2013). Self-care management strategies among individuals living with type 2 diabetes mellitus: nursing interventions. Nursing: Research and Reviews, 3, 99105.

Johns Hopkins University, 2010. The impact of Johns Hopkins in Baltimore City. Retrieved from: web.jhu.edu/administration/gcpa/EIR_PDFs/15358\%20BaltoCity1PgSum.

Kivimaki, M., Vahtera, J., Pentti, J., Virtanen, M., Elovainio, M., and H. Hemingway. (2007). Increased sickness absence in diabetic employees: what is the role of co-morbid conditions? Diabetes Medicine 24, 1043-1048. 
Lavigne, J.E., Phelps, C. E., Mashlin, A., and Ledar, W. M. (2003). Reductions in individual work productivity associated with type 2 diabetes mellitus. Pharmocoeconomics 21(15), 1123-1134.

National Cancer Institute (2005). Theory at a glance: A guide for health promotion practice. (pp. 57-59). U.S. Department of Health and Human Services. National Institutes of Health.

National Diabetes Information Clearinghouse (NDIC) of the U. S. Department of Health and Human Services (2011). National Diabetes Statistics. Retrieved from: http://www.diabetes.niddk.nih.gov/dm/pubs/statistics/\#Racial.

Pelletier, K. R. (2011). A review and analysis of the clinical and cost-effectiveness studies of comprehensive health promotion and disease management programs at the worksite. Journal of Occupational and Environmental Medicine, Oct $2011: 1$.

Peyrot M., Peeples M,. Tomky D., Charron-Prochownik D, \& Weaver T. (2007) AADE outcomes project and AADE/UPMC diabetes education outcomes project development of the American Association of Diabetes Educators' diabetes selfmanagement assessment report tool. Diabetes Educator, 33,(5), 818-826.

Philis-Tsimikas, A. \& Gallo, L. C. (2014). Implementing community-based diabetes programs: the Scripps Whittier Diabetes Institute experience. Current Diabetes Reports, 14(2):462.

Renders, C. M., Valk, G. D., Griffin, S. J., Wagner, E. von Eijk, J. T., \& Assendelft, W. J. J. (2009). Interventions to improve management of diabetes mellitus in primary care, outpatient, and community settings. The Cochrane Library, 1,1142. 
Rodbard, H. W., Fox, K. M., Grandy, S., \& Shield Study, G. (2009). Impact of obesity on work productivity and role disability in individuals with and at risk for diabetes mellitus. American Journal of Health Promotion, 23(5), 353-360.

Rogers, E. (1995). Diffusion of Innovations Fourth Edition. New York: The Free Press.

Skerjanc, A. (2001). Sickness absence in diabetic employees. Occupational Environmental Medicine, 58(7), 432-436.

Sylvia, M. L., Weiner, J. P., Nolan, M. T., Han, H., Brancati, F., \& White, K. (2012). Work limitations and their relationship to morbidity burden among academic Health center employees with diabetes. Workplace Health and Safety, 60(10), 425-434.

Thomas, P. D., \& Miceli, R. (2006). Evaluation of the "know your health" program for type 2 diabetes mellitus and hypertension in a large employer group. American Journal of Managed Care, 12(Speco), SP33-9.

Tshiananga, J. K., Kocher, S., Weber, C., Erny-Albrecht, K., Berndt, K., \& Neeser, K. (2012). The effect of nurse-led diabetes self-management education on glycosylated hemoglobin and cardiovascular risk factors: A meta-analysis. Diabetes Educator, 38(1), 108-123.

Tunceli, K., Bradley, C. J., Lafata, J., E., Pladevall, M., Divine, G. W., Goodman, A. C., and Vijan, S. (2007). Glycemic control and absenteeism among individuals with diabetes. Diabetes Care, 30(5), 1282-1285.

Tunceli, K.,Zeng, H., Haviv, Z. A., and Williams, L. K. (2009). Long-term projections for diabetes-related work loss and limitations among U. S. adults. Diabetes Research and Clinical Practice, 83, e23-e25. 
United States Census Bureau (2012). Race main: what is race? Retrieved 3/1/2014 from: http://www.census.gov/population/race/.

United States Census Bureau (2012). Baltimore City Quick Facts. Retrieved 3/1/14 from: http://quickfacts.census.gov/qfd/states/24/24510.html

United States Community Preventive Services Task Force (2002). Diabetes Prevention and Control: Self-Management Education. Retrieved 9/15/2012 from: http://www.thecommunityguide.org/diabetes/selfmgmteducation.html.

Wolf, A. M., Siadaty, M. S., Crowther, J. Q., Nadler, J. L., Wagner, D. L., Cavalieri, S. L., Elward, K. S., and Bovbjerg, V. E. (2009). Impact of lifestyle intervention on lost productivity and disability: Improving control with activity and nutrition. Journal of Occupational and Environmental Medicine, 51(2), 139-145. 
Appendix A

Tables 
APPENDIX A: Literature Reviewed

\begin{tabular}{|c|c|c|c|c|c|c|}
\hline Article/Study & Purpose of Study & $\begin{array}{l}\text { Study } \\
\text { design/type }\end{array}$ & Rigor and Validity & $\begin{array}{l}\text { Sample description } \\
\text { and number }\end{array}$ & $\begin{array}{l}\text { Type of } \\
\text { Analysis }\end{array}$ & $\begin{array}{l}\text { Major Findings and } \\
\text { Implications }\end{array}$ \\
\hline $\begin{array}{l}\text { Aldana, S.G., Merrill, } \\
\text { R. M., Price, K., Hardy, } \\
\text { A., and Hager, R. } \\
\text { (2005). Financial } \\
\text { impact of a } \\
\text { comprehensive } \\
\text { multisite workplace } \\
\text { health promotion } \\
\text { program. Journal of } \\
\text { Preventive Medicine, } \\
\text { 40, 131-137. }\end{array}$ & $\begin{array}{l}\text { To determine if } \\
\text { an employee } \\
\text { workplace health } \\
\text { promotion } \\
\text { program in } \\
\text { county school } \\
\text { district could } \\
\text { decrease health } \\
\text { care costs and } \\
\text { absenteeism } \\
\text { over two year } \\
\text { period. }\end{array}$ & $\begin{array}{l}\text { Comparison, } \\
\text { non-randomized } \\
\text { prospective } \\
\text { review of survey } \\
\text { information and } \\
\text { data collection. }\end{array}$ & $\begin{array}{l}\text { No randomization. } \\
\text { Voluntary } \\
\text { participation in } \\
\text { workplace } \\
\text { promotion program. } \\
\text { Data gathered from } \\
\text { those employees in } \\
\text { the insurance plan, } \\
\text { but } 5 \% \text { of the data } \\
\text { not available. }\end{array}$ & $\begin{array}{l}6,246 \text { employees of } \\
\text { one school district } \\
\text { employed fulltime } \\
\text { 1997-2002. 1,407 } \\
\text { participated in the } \\
\text { wellness program } \\
\text { one year. 1,264 } \\
\text { participated both } \\
\text { years. Majority } \\
\text { were } 50 \text { years or } \\
\text { older and female. }\end{array}$ & $\begin{array}{l}\text { SAS used with } \\
\text { chi-square test } \\
\text { and F statistic } \\
\text { used in analysis } \\
\text { of variance for } \\
\text { testing the null } \\
\text { hypothesis of } \\
\text { equality of } \\
\text { means. }\end{array}$ & $\begin{array}{l}\text { Short term minimal } \\
\text { difference in health } \\
\text { care costs between } \\
\text { participants and } \\
\text { nonparticipants. } \\
\text { Absenteeism } \\
\text { significantly less (20\%) } \\
\text { in participants and over } \\
\text { time and health care } \\
\text { costs reduced. Older } \\
\text { people had greatest } \\
\text { impact on } \\
\text { absenteeism. More } \\
\text { study needed over } \\
\text { time to determine if } \\
\text { health care costs are } \\
\text { impacted. }\end{array}$ \\
\hline $\begin{array}{l}\text { Boles, M., Pelletier, K., } \\
\text { and Lynch, W. (2004). } \\
\text { The relationship } \\
\text { between health risks } \\
\text { and work productivity. } \\
\text { Journal of } \\
\text { Occupational and } \\
\text { Environmental } \\
\text { Medicine, 46(7), 737- } \\
745 .\end{array}$ & $\begin{array}{l}\text { To examine if } \\
\text { there is a } \\
\text { relationship } \\
\text { between health } \\
\text { risks and self- } \\
\text { reported } \\
\text { productivity. }\end{array}$ & $\begin{array}{l}\text { Crosssectional } \\
\text { study with } \\
\text { survey data } \\
\text { looking at } \\
\text { relationship } \\
\text { between health } \\
\text { risks and self- } \\
\text { reported work } \\
\text { productivity } \\
\text { including } \\
\text { absences. }\end{array}$ & $\begin{array}{l}\text { No randomization. } \\
\text { All volunteer } \\
\text { participants. } \\
\text { Productivity by self- } \\
\text { report. } \\
\text { Incentives used to } \\
\text { increase } \\
\text { participation. } \\
\text { Data on work } \\
\text { productivity } \\
\text { obtained with a }\end{array}$ & $\begin{array}{l}\text { 2,264 employees at } \\
\text { a northeast } \\
\text { employer who } \\
\text { were members of a } \\
\text { corporate- } \\
\text { sponsored fitness } \\
\text { center. Majority of } \\
\text { subjects- females } \\
\text { less than } 45 \text { years } \\
\text { old. }\end{array}$ & $\begin{array}{l}\text { Analysis of } \\
\text { covariance } \\
\text { used to } \\
\text { examine } \\
\text { relationships. }\end{array}$ & $\begin{array}{l}\text { Risk factors correlated } \\
\text { with decreased } \\
\text { productivity and } \\
\text { increased work } \\
\text { absence. Presenteeism } \\
\text { greater than } \\
\text { absenteeism. Diabetes } \\
\text { was worst risk factor } \\
\text { related to decreased } \\
\text { productivity. } \\
\text { Interventions aiming to }\end{array}$ \\
\hline
\end{tabular}




\begin{tabular}{|c|c|c|c|c|c|c|}
\hline Article/Study & Purpose of Study & $\begin{array}{l}\text { Study } \\
\text { design/type }\end{array}$ & Rigor and Validity & $\begin{array}{l}\text { Sample description } \\
\text { and number }\end{array}$ & $\begin{array}{l}\text { Type of } \\
\text { Analysis }\end{array}$ & $\begin{array}{l}\text { Major Findings and } \\
\text { Implications }\end{array}$ \\
\hline & & & validated tool. & & & $\begin{array}{l}\text { decrease risks and } \\
\text { impact presenteeism } \\
\text { and absenteeism may } \\
\text { be valuable to } \\
\text { employers. }\end{array}$ \\
\hline $\begin{array}{l}\text { Burton, W. N., and } \\
\text { Connerty, C.M. (2002). } \\
\text { Worksite-based } \\
\text { diabetes disease } \\
\text { management } \\
\text { program. Disease } \\
\text { Management, 5(1), 1- } \\
8 .\end{array}$ & $\begin{array}{l}\text { To investigate } \\
\text { whether worksite } \\
\text { diabetes } \\
\text { education can } \\
\text { improve diabetes } \\
\text { control? }\end{array}$ & $\begin{array}{l}\text { Pre-test, post- } \\
\text { test with a } \\
\text { convenience } \\
\text { sample. No } \\
\text { control or } \\
\text { randomization. }\end{array}$ & $\begin{array}{l}\text { Education modules } \\
\text { given by certified } \\
\text { diabetes educator at } \\
\text { work. Initial } \\
\text { questionnaire about } \\
\text { diabetes knowledge, } \\
\text { symptoms, and } \\
\text { medical history } \\
\text { done, but not noted } \\
\text { what instrument } \\
\text { used or if validated. } \\
\text { Incentives used to } \\
\text { encourage } \\
\text { participation. Lab } \\
\text { evaluation done by } \\
\text { one lab and } \\
\text { processed the same } \\
\text { day. }\end{array}$ & $\begin{array}{l}53 \text { employees of a } \\
\text { banking institution } \\
\text { participated in } \\
\text { program and } 36 \\
\text { had repeat } \\
\text { laboratory testing } \\
\text { at three and six } \\
\text { months. Mean age } \\
\text { of } 45.2 \text {. Majority } \\
\text { were white } \\
\text { females. }\end{array}$ & $\begin{array}{l}\text { Analysis not } \\
\text { noted, but } \\
\text { appears to be } \\
\text { comparison of } \\
\text { means at } \\
\text { baseline, three } \\
\text { months, and } \\
\text { six months. }\end{array}$ & $\begin{array}{l}\text { Mean fasting glucose } \\
\text { and mean A1C } \\
\text { decreased three and six } \\
\text { months post program. } \\
\text { Recommended further } \\
\text { study of productivity, } \\
\text { improved identification } \\
\text { of employees at most } \\
\text { risk, assistance for } \\
\text { employees to } \\
\text { participate, and } \\
\text { measurement and } \\
\text { evaluation of results. }\end{array}$ \\
\hline $\begin{array}{l}\text { Cancelliere, C., } \\
\text { Cassidy, J. D., } \\
\text { Ammendolia, C. and } \\
\text { Cote, P. (2011). Are } \\
\text { workplace health } \\
\text { promotion programs } \\
\text { effective at improving } \\
\text { presenteeism in } \\
\text { workers? A }\end{array}$ & $\begin{array}{l}\text { To determine if } \\
\text { workplace health } \\
\text { promotion } \\
\text { programs } \\
\text { improve } \\
\text { presenteeism. }\end{array}$ & $\begin{array}{l}\text { Systematic } \\
\text { literature } \\
\text { review of } 47 \\
\text { studies } \\
\text { published } \\
\text { between } 1990 \\
\text { and } 2010.14 \\
\text { met criteria for } \\
\text { review. }\end{array}$ & $\begin{array}{l}\text { Studies with bias } \\
\text { eliminated from } \\
\text { review. Studies } \\
\text { without validated } \\
\text { tools to assess } \\
\text { presenteeism } \\
\text { excluded. Examined } \\
\text { only English } \\
\text { language studies. }\end{array}$ & $\begin{array}{l}\text { Included in review } \\
\text { five RCTs, five } \\
\text { cluster RCTs, one } \\
\text { interrupted time } \\
\text { series study, one } \\
\text { crossover design } \\
\text { study, one pre-post } \\
\text { study and one } \\
\text { quasi-experimental }\end{array}$ & $\begin{array}{l}\text { Summary of } \\
\text { studies. }\end{array}$ & $\begin{array}{l}\text { More research on } \\
\text { presenteeism needed. } \\
\text { Preliminary evidence } \\
\text { that workplace } \\
\text { programs can impact } \\
\text { presenteeism. } \\
\text { Successful programs } \\
\text { have supportive } \\
\text { workplace culture, }\end{array}$ \\
\hline
\end{tabular}




\begin{tabular}{|c|c|c|c|c|c|c|}
\hline Article/Study & Purpose of Study & \begin{tabular}{|l|} 
Study \\
design/type
\end{tabular} & Rigor and Validity & $\begin{array}{l}\text { Sample description } \\
\text { and number }\end{array}$ & $\begin{array}{l}\text { Type of } \\
\text { Analysis }\end{array}$ & $\begin{array}{l}\text { Major Findings and } \\
\text { Implications }\end{array}$ \\
\hline $\begin{array}{l}\text { systematic review and } \\
\text { best evidence } \\
\text { synthesis of the } \\
\text { literature. BMC Public } \\
\text { Health, } 11,395-406 .\end{array}$ & & & & study. & & $\begin{array}{l}\text { leadership, health risk } \\
\text { screening, and } \\
\text { individually-tailored } \\
\text { programs including } \\
\text { physical and } \\
\text { psychological } \\
\text { interventions. } \\
\text { Recommended studies } \\
\text { are done in a range of } \\
\text { workplace settings. } \\
\text { Diabetes noted as one } \\
\text { of the health } \\
\text { conditions increasing } \\
\text { presenteeism. }\end{array}$ \\
\hline $\begin{array}{l}\text { Carloti, C. A., Lavigne, } \\
\text { J. E., Stone, P., } \\
\text { Tortoretti, D. M., and } \\
\text { Chiverton, P. (2001). } \\
\text { Work site disease } \\
\text { management } \\
\text { outcomes: Expanding } \\
\text { the role of the APN. } \\
\text { Outcomes } \\
\text { Management for } \\
\text { Nursing Practice, 5(4), } \\
\text { 179-186. }\end{array}$ & $\begin{array}{l}\text { To examine } \\
\text { whether use of } \\
\text { advanced } \\
\text { practice nurses in } \\
\text { private doctor } \\
\text { offices at } \\
\text { worksites to } \\
\text { manage chronic } \\
\text { diseases } \\
\text { improves health } \\
\text { behaviors. }\end{array}$ & $\begin{array}{l}\text { Post- } \\
\text { intervention } \\
\text { survey whether } \\
\text { participants } \\
\text { experienced } \\
\text { behavior change } \\
\text { and/or better } \\
\text { understanding } \\
\text { related to their } \\
\text { chronic disease. }\end{array}$ & $\begin{array}{l}\text { No comparison } \\
\text { group, no } \\
\text { randomization, and } \\
\text { small sample. } \\
\text { Provider chose } \\
\text { participants. }\end{array}$ & $\begin{array}{l}\text { Worksite primary } \\
\text { care providers } \\
\text { given lists of } \\
\text { potential } \\
\text { participants from } \\
\text { employee data } \\
\text { base and provider } \\
\text { chose potential } \\
\text { subjects. } 54 \text { people } \\
\text { participated. } \\
\text { Majority were } \\
\text { educated, white } \\
\text { males. }\end{array}$ & $\begin{array}{l}\text { Chi-square was } \\
\text { used to } \\
\text { measure } \\
\text { behavior } \\
\text { change. }\end{array}$ & $\begin{array}{l}\text { Results significant for } \\
\text { patient reports of more } \\
\text { control of their disease } \\
\text { and more knowledge. } \\
\text { Future study could } \\
\text { examine health } \\
\text { outcomes. }\end{array}$ \\
\hline $\begin{array}{l}\text { Crawley, J., Rizzo, J. A., } \\
\text { and Haas, K. (2008). } \\
\text { The association of } \\
\text { diabetes with job } \\
\text { absenteeism costs }\end{array}$ & $\begin{array}{l}\text { To determine } \\
\text { whether } \\
\text { absenteeism } \\
\text { costs associated } \\
\text { with obesity are } \\
\end{array}$ & $\begin{array}{l}\text { Retrospective } \\
\text { data review } \\
\text { from Medical } \\
\text { Expenditure } \\
\text { Panel Survey }\end{array}$ & $\begin{array}{l}\text { MEPS database } \\
\text { designed to be } \\
\text { nationally } \\
\text { representative of } \\
\text { noninstitutionalized }\end{array}$ & $\begin{array}{l}\text { 19,402 employed } \\
\text { female adults. } \\
14,187 \text { men. Total } \\
\text { sample divided into } \\
\text { obese non- }\end{array}$ & $\begin{array}{l}\text { SAS used for } \\
\text { analysis. } \\
\text { Regression } \\
\text { performed to } \\
\text { predict }\end{array}$ & $\begin{array}{l}\text { Diabetes is strongly } \\
\text { predictive of } \\
\text { absenteeism among } \\
\text { obese and morbidly } \\
\text { obese. Recommended }\end{array}$ \\
\hline
\end{tabular}




\begin{tabular}{|c|c|c|c|c|c|c|}
\hline Article/Study & Purpose of Study & $\begin{array}{l}\text { Study } \\
\text { design/type }\end{array}$ & Rigor and Validity & $\begin{array}{l}\text { Sample description } \\
\text { and number }\end{array}$ & $\begin{array}{l}\text { Type of } \\
\text { Analysis }\end{array}$ & $\begin{array}{l}\text { Major Findings and } \\
\text { Implications }\end{array}$ \\
\hline $\begin{array}{l}\text { among obese and } \\
\text { morbidly obese } \\
\text { workers. Journal of } \\
\text { Occupational and } \\
\text { Environmental } \\
\text { Medicine, 50(5), 527- } \\
534 \text {. }\end{array}$ & $\begin{array}{l}\text { traceable to } \\
\text { diabetes. To } \\
\text { identify whether } \\
\text { after controlling } \\
\text { for diabetes do } \\
\text { obesity and } \\
\text { morbid obesity } \\
\text { act as predictors } \\
\text { of absenteeism } \\
\text { costs. }\end{array}$ & $\begin{array}{l}\text { (MEPS) } \\
\text { collected by the } \\
\text { Agency for } \\
\text { Health Care } \\
\text { Research and } \\
\text { Quality was } \\
\text { analyzed for } \\
\text { comparison. } \\
\text { Not RCT. }\end{array}$ & $\begin{array}{l}\text { civilian population } \\
\text { in the US. } \\
\text { Dependent on } \\
\text { proper Icd-9 coding } \\
\text { of diabetes to } \\
\text { capture data. }\end{array}$ & $\begin{array}{l}\text { diabetic, obese } \\
\text { diabetic, morbidly } \\
\text { obese nondiabetic, } \\
\text { and morbidly } \\
\text { obese diabetic. }\end{array}$ & $\begin{array}{l}\text { absenteeism } \\
\text { based on } \\
\text { obesity and/or } \\
\text { diabetes. }\end{array}$ & $\begin{array}{l}\text { employers support } \\
\text { obesity interventions } \\
\text { and diabetes } \\
\text { prevention. }\end{array}$ \\
\hline $\begin{array}{l}\text { DiBonaventura, M., } \\
\text { Link, C., Pollack, M. F., } \\
\text { Wagner, J., and } \\
\text { Williams, S.A. (2011). } \\
\text { The relationship } \\
\text { between patient- } \\
\text { reported tolerability } \\
\text { issues with oral anti- } \\
\text { diabetic agents and } \\
\text { work productivity } \\
\text { among patients having } \\
\text { type } 2 \text { diabetes. } \\
\text { Journal of } \\
\text { Occupational and } \\
\text { Environmental } \\
\text { Medicine, 53(2), 204- } \\
\text { 209. }\end{array}$ & $\begin{array}{l}\text { To examine the } \\
\text { relationship } \\
\text { between } \\
\text { reported oral } \\
\text { anti-diabetic } \\
\text { tolerability issues } \\
\text { and work } \\
\text { productivity. }\end{array}$ & $\begin{array}{l}\text { Convenience } \\
\text { sample survey. }\end{array}$ & $\begin{array}{l}\text { Participants invited } \\
\text { via email only. If no } \\
\text { internet use, no } \\
\text { participation. } \\
\text { Tolerability of } \\
\text { medications } \\
\text { assessed using the } \\
\text { Diabetes Symptom } \\
\text { Measure which has } \\
\text { been validated. The } \\
\text { instrument used to } \\
\text { obtain results on } \\
\text { work productivity } \\
\text { validated as well. }\end{array}$ & $\begin{array}{l}\text { 10,374 patients } \\
\text { with type } 2 \\
\text { diabetes identified } \\
\text { from a US national } \\
\text { internet-based } \\
\text { Health and } \\
\text { Wellness Survey. } \\
\text { 2,074 were eligible, } \\
\text { consented, and } \\
\text { completed the } \\
\text { survey. Majority } \\
\text { were white, male, } \\
\text { and retired. }\end{array}$ & $\begin{array}{l}\text { Chi square and } \\
\text { one-way } \\
\text { ANOVA was } \\
\text { used. }\end{array}$ & $\begin{array}{l}\text { Majority of patients } \\
\text { surveyed reported } \\
\text { having a problem with } \\
\text { their oral medication. } \\
\text { As tolerability } \\
\text { problems increased, so } \\
\text { did impairment of work } \\
\text { activity. Presenteeism } \\
\text { more problematic than } \\
\text { absenteeism which } \\
\text { could go unnoticed. } \\
\text { Therapies should be } \\
\text { considered based on } \\
\text { not only therapeutic } \\
\text { effects, but also } \\
\text { tolerability. Employers } \\
\text { should encourage } \\
\text { healthy behaviors and } \\
\text { health education. }\end{array}$ \\
\hline
\end{tabular}




\begin{tabular}{|c|c|c|c|c|c|c|}
\hline Article/Study & Purpose of Study & $\begin{array}{l}\text { Study } \\
\text { design/type }\end{array}$ & Rigor and Validity & $\begin{array}{l}\text { Sample description } \\
\text { and number }\end{array}$ & $\begin{array}{l}\text { Type of } \\
\text { Analysis }\end{array}$ & $\begin{array}{l}\text { Major Findings and } \\
\text { Implications }\end{array}$ \\
\hline $\begin{array}{l}\text { Druss, B. G., Marcus, } \\
\text { S. C., Olfson, M., } \\
\text { Tanielian, T., Elinson, } \\
\text { L., and Pincus, H.A. } \\
\text { (2001). Comparing the } \\
\text { national economic } \\
\text { burden of five chronic } \\
\text { conditions. } \\
\text { Health Affairs, 20(6), } \\
\text { 233-241. }\end{array}$ & $\begin{array}{l}\text { To compare the } \\
\text { health care cost } \\
\text { burden and work } \\
\text { loss cost } \\
\text { between five } \\
\text { chronic } \\
\text { conditions of } \\
\text { mood disorder, } \\
\text { diabetes, heart } \\
\text { disease, } \\
\text { hypertension, } \\
\text { and asthma. }\end{array}$ & $\begin{array}{l}\text { Data analysis of } \\
\text { data from the } \\
\text { Medical } \\
\text { Expenditure } \\
\text { Panel Survey } \\
\text { conducted by } \\
\text { AHRQ. }\end{array}$ & $\begin{array}{l}\text { Conditions were by } \\
\text { self-report. Indirect } \\
\text { costs were difficult } \\
\text { to measure. }\end{array}$ & $\begin{array}{l}\text { Data was taken } \\
\text { from a nationally } \\
\text { representative } \\
\text { sample of } 23,230 \\
\text { US residents. }\end{array}$ & $\begin{array}{l}\text { Proportion of } \\
\text { costs from } \\
\text { illness was } \\
\text { examined. }\end{array}$ & $\begin{array}{l}\text { Top three health care } \\
\text { costs were heart } \\
\text { disease, mood } \\
\text { disorder, and diabetes. } \\
\text { Top three for work loss } \\
\text { were heart disease, } \\
\text { asthma, and mood } \\
\text { disorder. Evaluation of } \\
\text { interventions directed } \\
\text { at people with most } \\
\text { costly conditions would } \\
\text { help determine if costs } \\
\text { could be impacted. }\end{array}$ \\
\hline $\begin{array}{l}\text { Kivimaki, M., Vahtera, } \\
\text { J., Pentti, J., Virtanen, } \\
\text { M., Elovainio, M., and } \\
\text { H. Hemingway. } \\
\text { (2007). Increased } \\
\text { sickness absence in } \\
\text { diabetic employees: } \\
\text { What is the role of } \\
\text { comorbid conditions? } \\
\text { Diabetes Medicine, 24, } \\
\text { 1043-1048. }\end{array}$ & $\begin{array}{l}\text { To examine the } \\
\text { comorbid } \\
\text { conditions } \\
\text { responsible for } \\
\text { sick day absences } \\
\text { in workers with } \\
\text { diabetes. }\end{array}$ & $\begin{array}{l}\text { Record review } \\
\text { of physician } \\
\text { certified } \\
\text { illnesses lasting } \\
\text { more than three } \\
\text { days long to } \\
\text { identify reason } \\
\text { for missed work } \\
\text { and amounts. }\end{array}$ & $\begin{array}{l}\text { Data based on self- } \\
\text { report. }\end{array}$ & $\begin{array}{l}638 \text { diabetic } \\
\text { patients and } \\
32,510 \text { non- } \\
\text { diabetic patients in } \\
\text { Finland who were } \\
\text { in the public } \\
\text { sector. Patients } \\
\text { were surveyed by } \\
\text { mail. }\end{array}$ & $\begin{array}{l}\text { Distribution of } \\
\text { sickness } \\
\text { absences } \\
\text { examined. Cox } \\
\text { proportional } \\
\text { hazards models } \\
\text { used to study } \\
\text { the association } \\
\text { of diabetes and } \\
\text { other } \\
\text { conditions with } \\
\text { sickness } \\
\text { absences. }\end{array}$ & $\begin{array}{l}\text { People with diabetes } \\
\text { had } 2.15 \text { fold increases } \\
\text { in absences. } \\
\text { Cardiovascular disease } \\
\text { accounted for } 7 \% \text { of } \\
\text { absences. } 55 \% \text { due to } \\
\text { mood disorder and } \\
\text { respiratory illness. } \\
\text { Further study with } \\
\text { other work groups } \\
\text { should be done to } \\
\text { compare results. }\end{array}$ \\
\hline
\end{tabular}




\begin{tabular}{|c|c|c|c|c|c|c|}
\hline Article/Study & Purpose of Study & $\begin{array}{l}\text { Study } \\
\text { design/type }\end{array}$ & Rigor and Validity & $\begin{array}{l}\text { Sample description } \\
\text { and number }\end{array}$ & $\begin{array}{l}\text { Type of } \\
\text { Analysis }\end{array}$ & $\begin{array}{l}\text { Major Findings and } \\
\text { Implications }\end{array}$ \\
\hline $\begin{array}{l}\text { Lavigne, J.E., Phelps, C. } \\
\text { E., Mashlin, A., and } \\
\text { Ledar, W. M. (2003). } \\
\text { Reductions in } \\
\text { individual work } \\
\text { productivity } \\
\text { associated with type } 2 \\
\text { diabetes mellitus. } \\
\text { Pharmocoeconomics, } \\
\text { 21(15), 1123-1134. }\end{array}$ & $\begin{array}{l}\text { To assess impact } \\
\text { of type } 2 \\
\text { diabetes on work } \\
\text { productivity, } \\
\text { absences, and } \\
\text { value of lost } \\
\text { time. }\end{array}$ & $\begin{array}{l}\text { Telephone } \\
\text { survey. }\end{array}$ & $\begin{array}{l}\text { No comparison of } \\
\text { employees across } \\
\text { similar jobs. The } \\
\text { control group only } \\
\text { had } 35 \% \\
\text { enrollment. } \\
\text { Declines in work } \\
\text { productivity were } \\
\text { self-reported. }\end{array}$ & $\begin{array}{l}472 \text { subjects } \\
\text { identified from } \\
\text { claims data of } \\
\text { employed NY state } \\
\text { residents in a } \\
\text { major US } \\
\text { corporation in two } \\
\text { managed care } \\
\text { companies. } 78 \text { had } \\
\text { type } 2 \text { diabetes. } \\
\text { Stratified random } \\
\text { sampling of the } \\
\text { data pool to create } \\
\text { control group. The } \\
\text { diabetes group had } \\
\text { a higher proportion } \\
\text { of people of } \\
\text { minority race, but } \\
\text { consistent with the } \\
\text { US population with } \\
\text { diabetes. }\end{array}$ & $\begin{array}{l}\text { Descriptive } \\
\text { using t-tests. }\end{array}$ & $\begin{array}{l}\text { Reduced productivity } \\
\text { with type } 2 \text { diabetes. } \\
\text { No significant } \\
\text { differences between } \\
\text { absences. Job } \\
\text { dissatisfaction } \\
\text { correlated with } \\
\text { decreased attendance. } \\
\text { Work efficiency } \\
\text { decreased with every } \\
\text { year a person has } \\
\text { diabetes. Depression } \\
\text { in diabetes correlated } \\
\text { with absence and } \\
\text { decreased work } \\
\text { productivity. } \\
\text { Recommend examining } \\
\text { relationship further. } \\
\text { Corporate culture } \\
\text { should work towards } \\
\text { improved job } \\
\text { satisfaction. }\end{array}$ \\
\hline
\end{tabular}




\begin{tabular}{|c|c|c|c|c|c|c|}
\hline Article/Study & Purpose of Study & \begin{tabular}{|l|} 
Study \\
design/type
\end{tabular} & Rigor and Validity & $\begin{array}{l}\text { Sample description } \\
\text { and number }\end{array}$ & $\begin{array}{l}\text { Type of } \\
\text { Analysis }\end{array}$ & $\begin{array}{l}\text { Major Findings and } \\
\text { Implications }\end{array}$ \\
\hline $\begin{array}{l}\text { Pelletier, K. (2011). A } \\
\text { Review and Analysis of } \\
\text { the Clinical and Cost- } \\
\text { effectiveness } \\
\text { Studies of } \\
\text { Comprehensive Health } \\
\text { Promotion and } \\
\text { Disease } \\
\text { Management } \\
\text { Programs at the } \\
\text { Worksite. Journal of } \\
\text { Occupational and } \\
\text { Environmental } \\
\text { Medicine, Volume 53, } \\
\text { Number 11, 1310- } \\
\text { 1331. }\end{array}$ & $\begin{array}{l}\text { To examine } \\
\text { clinical and cost } \\
\text { outcomes of } 27 \\
\text { worksite } \\
\text { education } \\
\text { studies. }\end{array}$ & $\begin{array}{l}\text { Systematic } \\
\text { review of the } \\
\text { literature }\end{array}$ & $\begin{array}{l}\text { Used peer-reviewed } \\
\text { studies from the } \\
\text { two most recent } \\
\text { years. }\end{array}$ & $\begin{array}{l}27 \text { studies } \\
\text { including } 7 \\
\text { randomized } \\
\text { controlled trials. }\end{array}$ & $\begin{array}{l}\text { Reviewed } \\
\text { trends in } \\
\text { employee } \\
\text { worksite } \\
\text { education } \\
\text { interventions } \\
\text { and studies }\end{array}$ & $\begin{array}{l}\text { Studies are positive for } \\
\text { improved employee } \\
\text { outcomes. Best results } \\
\text { come from studies } \\
\text { where employees feel } \\
\text { supported by the } \\
\text { corporation, have input } \\
\text { into what they need, } \\
\text { and consistent follow- } \\
\text { up. }\end{array}$ \\
\hline $\begin{array}{l}\text { Rodbard, H. W., Fox, } \\
\text { and Grundy, S. (2009). } \\
\text { Impact of obesity on } \\
\text { work productivity and } \\
\text { role disability in } \\
\text { individuals with and at } \\
\text { risk for diabetes } \\
\text { mellitus. American } \\
\text { Journal of Health } \\
\text { Promotion, 23(5):353- } \\
60 \text {. }\end{array}$ & $\begin{array}{l}\text { To examine the } \\
\text { impact of obesity } \\
\text { and diabetes on } \\
\text { work absence, } \\
\text { productivity, and } \\
\text { problems with } \\
\text { work, social, and } \\
\text { family life. }\end{array}$ & $\begin{array}{l}\text { Stratified } \\
\text { random sample. } \\
\text { Cross-sectional } \\
\text { analysis of } \\
\text { survey data. }\end{array}$ & $\begin{array}{l}\text { Surveyed voluntary } \\
\text { participants. } \\
\text { Use of Likert scale. } \\
\text { Do not know if work } \\
\text { wellness programs } \\
\text { have impact on the } \\
\text { groups observed. } \\
\text { Do not know if } \\
\text { obese people lose } \\
\text { weight, does } \\
\text { impairment } \\
\text { decrease. } \\
\text { Response rate } \\
63.7 \% .\end{array}$ & $\begin{array}{l}\text { Surveyed head of } \\
200,000 \text { US } \\
\text { households } \\
\text { containing up to } \\
\text { four people } 18 \\
\text { years old or older. } \\
\text { Representative of } \\
\text { the US population. } \\
\text { Of working } \\
\text { individuals } 25 \% \\
\text { had type } 2 \text { diabetes }\end{array}$ & $\begin{array}{l}\text { BMI categories } \\
\text { compared } \\
\text { using analysis } \\
\text { of variance. }\end{array}$ & $\begin{array}{l}\text { Obese people had } \\
\text { highest impairment of } \\
\text { work, social, and family } \\
\text { life regardless of } \\
\text { diabetes status or risk } \\
\text { level. Diabetes and } \\
\text { obesity were } \\
\text { independent predictors } \\
\text { of overall impairment. } \\
\text { In people with } \\
\text { diabetes, lower } \\
\text { socioeconomic status, } \\
\text { women, and younger } \\
\text { age had more } \\
\text { impairment. Further } \\
\text { studies needed to look }\end{array}$ \\
\hline
\end{tabular}




\begin{tabular}{|c|c|c|c|c|c|c|}
\hline Article/Study & Purpose of Study & $\begin{array}{l}\text { Study } \\
\text { design/type }\end{array}$ & Rigor and Validity & $\begin{array}{l}\text { Sample description } \\
\text { and number }\end{array}$ & $\begin{array}{l}\text { Type of } \\
\text { Analysis }\end{array}$ & $\begin{array}{l}\text { Major Findings and } \\
\text { Implications }\end{array}$ \\
\hline & & & & & & $\begin{array}{l}\text { at obesity and diabetes } \\
\text { treatment. }\end{array}$ \\
\hline $\begin{array}{l}\text { Skerjanc, A. (2001). } \\
\text { Sickness absence in } \\
\text { diabetic employees. } \\
\text { Journal of } \\
\text { Occupational } \\
\text { Environmental } \\
\text { Medicine, 58(7), 432- } \\
436 .\end{array}$ & $\begin{array}{l}\text { To compare } \\
\text { absenteeism } \\
\text { among } \\
\text { employees with } \\
\text { and without } \\
\text { diabetes. }\end{array}$ & $\begin{array}{l}\text { Cross sectional } \\
\text { case-control } \\
\text { study with a } \\
\text { random sample } \\
\text { of } 400 \text { diabetic } \\
\text { and } 400 \\
\text { nondiabetic } \\
\text { employees } 21-- \\
50 \text { years old } \\
\text { matched for age } \\
\text { and sex. }\end{array}$ & $\begin{array}{l}\text { Data was obtained } \\
\text { from employee } \\
\text { clinic records. }\end{array}$ & $\begin{array}{l}\text { The randomized } \\
\text { sample consisted } \\
\text { of } 61.2 \% \text { of men } \\
(245) \text { and } 38.8 \% \text { of } \\
\text { women (155) with } \\
\text { a mean age of } 42.5 \\
\text { years. }\end{array}$ & $\begin{array}{l}\text { Non- } \\
\text { parametric } \\
\text { statistics were } \\
\text { used (chi( } 2 \text { ) } \\
\text { test, Wilcoxon } \\
\text { matched pairs } \\
\text { test). }\end{array}$ & $\begin{array}{l}\text { People with diabetes } \\
\text { had significantly more } \\
\text { absences due to illness } \\
\text { and when they were } \\
\text { absent, the number of } \\
\text { days was greater. } \\
\text { Implication is to help } \\
\text { people control diabetes } \\
\text { and complications. }\end{array}$ \\
\hline $\begin{array}{l}\text { Sylvia, M. L., Weiner, J. } \\
\text { P., Nolan, M. T., Han, } \\
\text { H., Brancati, F., and } \\
\text { White, K. (2012). } \\
\text { Work limitations and } \\
\text { their relationship to } \\
\text { morbidity burden } \\
\text { among academic } \\
\text { health center } \\
\text { employees with }\end{array}$ & $\begin{array}{l}\text { To determine } \\
\text { prevalence of } \\
\text { work limitations } \\
\text { and relationship } \\
\text { to morbidity } \\
\text { burden (illness } \\
\text { severity). }\end{array}$ & $\begin{array}{l}\text { Cross-sectional } \\
\text { design using } \\
\text { employee } \\
\text { health claims } \\
\text { data. }\end{array}$ & $\begin{array}{l}\text { Work limitations } \\
\text { questionnaire } \\
\text { (WLQ) and adjusted } \\
\text { clinical groups (ACG) } \\
\text { for assessing } \\
\text { morbidity burden } \\
\text { with established } \\
\text { reliability and } \\
\text { validity. }\end{array}$ & $\begin{array}{l}485 \text { employees of a } \\
\text { large urban } \\
\text { academic medical } \\
\text { center. } \\
83 \% \text { female with a } \\
\text { mean age of } 50 .\end{array}$ & $\begin{array}{l}\text { Comparison of } \\
\text { means and } \\
\text { odds ratio. } \\
\text { Regression to } \\
\text { test association } \\
\text { between } \\
\text { higher } \\
\text { morbidity and } \\
\text { work } \\
\text { limitations. }\end{array}$ & $\begin{array}{l}72 \% \text { reported work } \\
\text { limitations. Those with } \\
\text { higher morbidity had } \\
\text { more work limitations. } \\
\text { Employers can support } \\
\text { employees with } \\
\text { diabetes and nurses } \\
\text { can deliver education } \\
\text { to employees and } \\
\text { administration. }\end{array}$ \\
\hline
\end{tabular}




\begin{tabular}{|c|c|c|c|c|c|c|}
\hline Article/Study & Purpose of Study & $\begin{array}{l}\text { Study } \\
\text { design/type }\end{array}$ & Rigor and Validity & $\begin{array}{l}\text { Sample description } \\
\text { and number }\end{array}$ & $\begin{array}{l}\text { Type of } \\
\text { Analysis }\end{array}$ & $\begin{array}{l}\text { Major Findings and } \\
\text { Implications }\end{array}$ \\
\hline \multicolumn{7}{|l|}{$\begin{array}{l}\text { diabetes. Workplace } \\
\text { Health and Safety, } \\
60(10), 425-434 .\end{array}$} \\
\hline $\begin{array}{l}\text { Thomas, P. D. and } \\
\text { Miceli, R. (2006). } \\
\text { Evaluation of the } \\
\text { Know Your Health } \\
\text { program for type } 2 \\
\text { diabetes mellitus and } \\
\text { hypertension in a large } \\
\text { employer group. The } \\
\text { American Journal of } \\
\text { Managed Care, 12, } \\
\text { SP33-SP39. }\end{array}$ & $\begin{array}{l}\text { To evaluate the } \\
\text { effect of } \\
\text { employer } \\
\text { diabetes } \\
\text { educational } \\
\text { intervention on } \\
\text { clinical outcomes } \\
\text { and compliance } \\
\text { with medical } \\
\text { therapy in } \\
\text { patients with } \\
\text { type } 2 \text { diabetes } \\
\text { and/or } \\
\text { hypertension. }\end{array}$ & $\begin{array}{l}\text { Randomized } \\
\text { unblinded trial. }\end{array}$ & $\begin{array}{l}\text { The study utilized } \\
\text { program called } \\
\text { Know Your Health } \\
\text { that integrated } \\
\text { established } \\
\text { culturally-sensitive } \\
\text { health education } \\
\text { practices for } \\
\text { diabetes and } \\
\text { hypertension with } \\
\text { communication } \\
\text { strategies designed } \\
\text { for low functional } \\
\text { health literacy. } \\
\text { Study team } \\
\text { evaluated A1C and } \\
\text { blood pressure. } \\
\text { Employees could } \\
\text { join a fitness } \\
\text { program and all } \\
\text { were encouraged to } \\
\text { see their providers. }\end{array}$ & $\begin{array}{l}347 \text { employees of } \\
\text { Lockheed Martin in } \\
\text { Georgia and } \\
\text { Mississippi } \\
\text { diagnosed with } \\
\text { diabetes and/or } \\
\text { hypertension } 18 \\
\text { years or older were } \\
\text { randomized to } \\
\text { intervention or } \\
\text { usual care. } \\
\text { Average age range } \\
\text { from 22-80 years. } \\
\text { The majority were } \\
\text { white males. }\end{array}$ & $\begin{array}{l}\text { Analysis cohort } \\
\text { included those } \\
\text { not at goal for } \\
\text { glucose or } \\
\text { blood pressure } \\
\text { at baseline and } \\
\text { then at } 3 \text { and } 6 \\
\text { month follow- } \\
\text { up. SAS was } \\
\text { used to } \\
\text { perform chi- } \\
\text { square. }\end{array}$ & $\begin{array}{l}\text { With small numbers of } \\
\text { people with diabetes, } \\
\text { no significant } \\
\text { difference was seen in } \\
\text { pre A1C versus post } \\
\text { A1C. At } 6 \text { six months, } \\
\text { blood pressure control } \\
\text { in the intervention } \\
\text { group was significantly } \\
\text { better. }\end{array}$ \\
\hline $\begin{array}{l}\text { Tunceli, K., Bradley, C. } \\
\text { J., Lafata, J., E., } \\
\text { Pladevall, M., Divine, } \\
\text { G. W., Goodman, A. C., } \\
\text { and Vijan, S. (2007). } \\
\text { Glycemic control and } \\
\text { absenteeism among }\end{array}$ & $\begin{array}{l}\text { To determine if } \\
\text { control of } \\
\text { glucose can } \\
\text { reduce } \\
\text { absenteeism in } \\
\text { people with type } \\
2 \text { diabetes. To }\end{array}$ & $\begin{array}{l}\text { Telephone } \\
\text { survey and data } \\
\text { analysis from } \\
\text { record review. }\end{array}$ & $\begin{array}{l}\text { Self-reported } \\
\text { absenteeism. } \\
\text { Causation could not } \\
\text { be determined. No } \\
\text { note made } \\
\text { concurrent } \\
\text { medications. } 13\end{array}$ & $\begin{array}{l}27,407 \text { people } \\
\text { identified from } \\
\text { administrative data } \\
\text { from a medical } \\
\text { group in Michigan } \\
\text { between June } 2003 \\
\text { and May } 2004 .\end{array}$ & $\begin{array}{l}\text { Multivariate } \\
\text { analysis with } \\
\text { comparison of } \\
\text { means. }\end{array}$ & $\begin{array}{l}\text { Poor glycemic control } \\
\text { related to increased } \\
\text { absenteeism. In men, } \\
\text { poor lipid control also } \\
\text { related to increased } \\
\text { absenteeism. } \\
\text { Recommended review }\end{array}$ \\
\hline
\end{tabular}




\begin{tabular}{|c|c|c|c|c|c|c|}
\hline Article/Study & Purpose of Study & $\begin{array}{l}\text { Study } \\
\text { design/type }\end{array}$ & Rigor and Validity & $\begin{array}{l}\text { Sample description } \\
\text { and number }\end{array}$ & $\begin{array}{l}\text { Type of } \\
\text { Analysis }\end{array}$ & $\begin{array}{l}\text { Major Findings and } \\
\text { Implications }\end{array}$ \\
\hline $\begin{array}{l}\text { individuals with } \\
\text { diabetes. Diabetes } \\
\text { Care, 30(5), 1282- } \\
1285 .\end{array}$ & $\begin{array}{l}\text { examine the } \\
\text { relationship } \\
\text { between } \\
\text { absenteeism and } \\
\text { glucose, lipids, } \\
\text { and blood } \\
\text { pressure control } \\
\text { in people with } \\
\text { diabetes. }\end{array}$ & & $\begin{array}{l}\text { people were } \\
\text { excluded because of } \\
\text { language barriers. }\end{array}$ & $\begin{array}{l}\text { Those tested for } \\
\text { A1C taken from } \\
\text { that group }(11,324) \\
\text { and then a random } \\
\text { sample of } 1,000 \\
\text { patients taken } \\
\text { from those. } \\
\text { Age range was } 30 \\
\text { to } 64 \text { years. }\end{array}$ & & $\begin{array}{l}\text { of quality of care to } \\
\text { employees. }\end{array}$ \\
\hline $\begin{array}{l}\text { Tunceli, K.,Zeng, H., } \\
\text { Haviv, Z. A., and } \\
\text { Williams, L. K. (2009). } \\
\text { Long-term projections } \\
\text { for diabetes-related } \\
\text { work loss and } \\
\text { limitations among U. } \\
\text { S. adults. Diabetes } \\
\text { Research and Clinical } \\
\text { Practice, 83, e23-e25. }\end{array}$ & $\begin{array}{l}\text { To project } \\
\text { diabetes-related } \\
\text { productivity } \\
\text { losses in the } \\
\text { future through } \\
2050 .\end{array}$ & $\begin{array}{l}\text { Data analysis } \\
\text { with estimation } \\
\text { from record } \\
\text { review. } \\
\text { Years 1997-2005 } \\
\text { were used. } \\
\text { Employment } \\
\text { status, work } \\
\text { disability, and } \\
\text { presence of } \\
\text { work limitations } \\
\text { were the } \\
\text { primary } \\
\text { outcomes. }\end{array}$ & $\begin{array}{l}\text { Estimation based on } \\
\text { current data. } \\
\text { Relationship may } \\
\text { change over time. } \\
\text { Some data is self- } \\
\text { reported. }\end{array}$ & $\begin{array}{l}\text { Data from the } \\
\text { National Health } \\
\text { Interview Survey } \\
\text { and the U. S. } \\
\text { Census Bureau } \\
\text { used to project } \\
\text { diabetes-related } \\
\text { productivity losses } \\
\text { through } 2050 \text {. }\end{array}$ & Estimation. & $\begin{array}{l}\text { In people aged 20-44 } \\
\text { years, diabetes } \\
\text { associated with } \\
\text { increased } \\
\text { unemployment, } \\
\text { disability, and work } \\
\text { limitations. In } 2050 \text {, } \\
\text { estimated } 1.46 \text { million } \\
\text { will not work due to } \\
\text { diabetes and } 780,000 \\
\text { will have work } \\
\text { limitations. Suggest } \\
\text { looking to } \\
\text { interventions to lessen } \\
\text { the impact of diabetes } \\
\text { on workers. }\end{array}$ \\
\hline $\begin{array}{l}\text { Wolf, A. M., Siadaty, } \\
\text { M. S., Crowther, J. Q., } \\
\text { Nadler, J. L., Wagner, } \\
\text { D. L., Cavalieri, S. L., } \\
\text { Elward, K. S., and } \\
\text { Bovbjerg, V. E. (2009). }\end{array}$ & $\begin{array}{l}\text { To evaluate the } \\
\text { effectiveness of } \\
\text { an employee } \\
\text { lifestyle } \\
\text { intervention on } \\
\text { reducing work }\end{array}$ & $\begin{array}{l}\text { Randomized } \\
\text { controlled trial. } \\
\text { Dependent } \\
\text { variables } \\
\text { included weight } \\
\text { loss, waist }\end{array}$ & $\begin{array}{l}\text { Small study. } \\
\text { Most participants } \\
\text { were Caucasian. } \\
\text { Incentive for } \\
\text { participation. }\end{array}$ & $\begin{array}{l}147 \text { health plan } \\
\text { members with type } \\
2 \text { diabetes and } \\
\text { obesity for a } 12 \\
\text { month period. } \\
\text { Mean entry A1c }\end{array}$ & $\begin{array}{l}\text { Intention to } \\
\text { treat. } \\
\mathrm{F} \text { tests of } \\
\text { changes in } \\
\text { weight, waist } \\
\text { circumfer- }\end{array}$ & $\begin{array}{l}\text { Treatment group had } \\
\text { greater weight loss, } \\
\text { reduced waist } \\
\text { circumference, } \\
\text { reduced A1C, reduced } \\
\text { medication use, less }\end{array}$ \\
\hline
\end{tabular}




\begin{tabular}{|l|l|l|l|l|l|l|}
\hline Article/Study & Purpose of Study & $\begin{array}{l}\text { Study } \\
\text { design/type }\end{array}$ & Rigor and Validity & $\begin{array}{l}\text { Sample description } \\
\text { and number }\end{array}$ & $\begin{array}{l}\text { Type of } \\
\text { Analysis }\end{array}$ & $\begin{array}{l}\text { Major Findings and } \\
\text { Implications }\end{array}$ \\
\hline $\begin{array}{l}\text { Impact of lifestyle } \\
\text { intervention on lost } \\
\text { productivity and } \\
\text { disability: Improving } \\
\text { control with activity } \\
\text { and nutrition. Journal } \\
\text { of Occupational and } \\
\begin{array}{l}\text { Environmental } \\
\text { Medicine, 51(2), 139- }\end{array}\end{array}$ & $\begin{array}{l}\text { loss and disability } \\
\text { days. }\end{array}$ & $\begin{array}{l}\text { circumference, } \\
\text { A1C, fasting } \\
\text { lipid levels, } \\
\text { medication use, } \\
\text { and quality of } \\
\text { life. }\end{array}$ & & $\begin{array}{l}\text { was 7.7. Majority } \\
\text { were white } \\
\text { females. }\end{array}$ & $\begin{array}{l}\text { ence, A1C, and } \\
\text { medication } \\
\text { use. }\end{array}$ & $\begin{array}{l}\text { missed work, and } \\
\text { improved quality of } \\
\text { life. . More frequent } \\
\text { contact with case } \\
\text { managers correlated to } \\
\text { greater weight loss. } \\
\text { Glycemic control } \\
\text { measures were } \\
\text { modest, but overall } \\
\text { program points to } \\
\text { ability of case } \\
\text { managers to impact } \\
\text { diabetes. }\end{array}$ \\
& & & & \\
& & & & \\
\end{tabular}


Table 1

Characteristics of the Study Population

\begin{tabular}{|c|c|c|}
\hline Variable & $\begin{array}{l}\text { Total Population } \\
(n=20)\end{array}$ & Percentage \\
\hline \multicolumn{3}{|l|}{ Sex } \\
\hline Male & 6 & 30 \\
\hline Female & 14 & 70 \\
\hline \multicolumn{3}{|l|}{$\begin{array}{l}\text { Age (years) } \\
\text { (mean=54) }\end{array}$} \\
\hline $18-40$ & 3 & 15 \\
\hline $41-60$ & 16 & 80 \\
\hline$>60$ & 1 & 5 \\
\hline \multicolumn{3}{|l|}{ Ethnicity } \\
\hline Black/African-American & 12 & 60 \\
\hline White & 7 & 35 \\
\hline Asian & 1 & 5 \\
\hline \multicolumn{3}{|l|}{ Type of Diabetes } \\
\hline Type 1 & 1 & 5 \\
\hline Type 2 & 19 & 95 \\
\hline \multicolumn{3}{|l|}{$\begin{array}{l}\text { Diabetes Diagnosis (years) } \\
\text { (mean=7.7) }\end{array}$} \\
\hline$<5$ & 8 & 40 \\
\hline $5-10$ & 6 & 30 \\
\hline $11-16$ & 5 & 25 \\
\hline$>16$ & 1 & 5 \\
\hline
\end{tabular}


Table 2

Behavioral Dashboard Score for Self-Management Goal Attainment (Peyrot et al., 2007)

Score (percent towards goal)

$\mathrm{n}$

$5(100) \quad$ lab results indicate improvement $\quad 8$

4 (75) perceived health improvement 5

3 (50) changes becoming habits 4

2 (25) making changes with minor setbacks 2

1 (0) no progress 1 
Appendix B

Figures 


\begin{tabular}{|c|c|}
\hline Innovation development- & $\begin{array}{l}\text { Development of the diabetes } \\
\text { education program, including } \\
\text { assessment, planning, and review of } \\
\text { the research. }\end{array}$ \\
\hline Dissemination & $\begin{array}{l}\text { Identify communication channels in } \\
\text { the medical institution to disseminate } \\
\text { information about the diabetes } \\
\text { education program. }\end{array}$ \\
\hline Adoption - & $\begin{array}{l}\text { Communication channels promote the } \\
\text { program and employees schedule } \\
\text { appointments for the class or an } \\
\text { education visit as "early adopters". } \\
\text { Those channels which do not promote } \\
\text { the program or employees who do not } \\
\text { attend are "laggards". }\end{array}$ \\
\hline Implementation- & $\begin{array}{l}\text { Employees participate in the } \\
\text { education program, have } \mathrm{A} 1 \mathrm{C} \\
\text { checked, provide information about } \\
\text { days absent and ER/hospital visits, } \\
\text { choose a self-management goal, and } \\
\text { evaluate education. }\end{array}$ \\
\hline Maintenance & $\begin{array}{l}\text { Evaluation of the outcomes of } \mathrm{A} 1 \mathrm{C} \text {, } \\
\text { days absent, ER/hospital visits, } \\
\text { attainment of self-management goal, } \\
\text { and participants satisfaction. Review } \\
\text { program, barriers, consider changes } \\
\text { and implications. }\end{array}$ \\
\hline
\end{tabular}

Figure 1. Steps in the Diffusion of Innovations model (Rogers, 1995) applied to the worksite diabetes education program. 


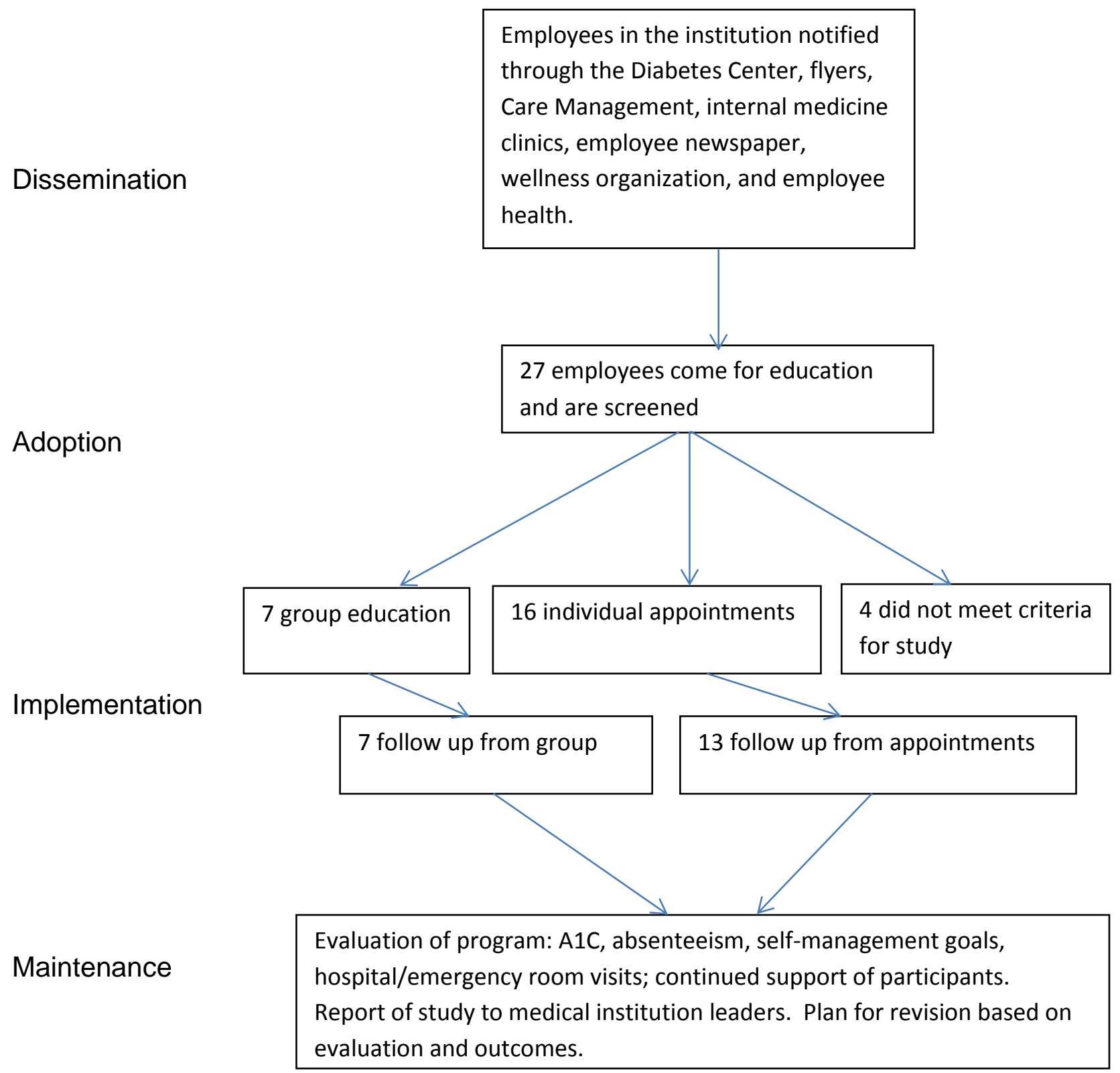

Figure 2. Flow of education program and relation to steps in Rogers (1995) Diffusion of Innovations. 


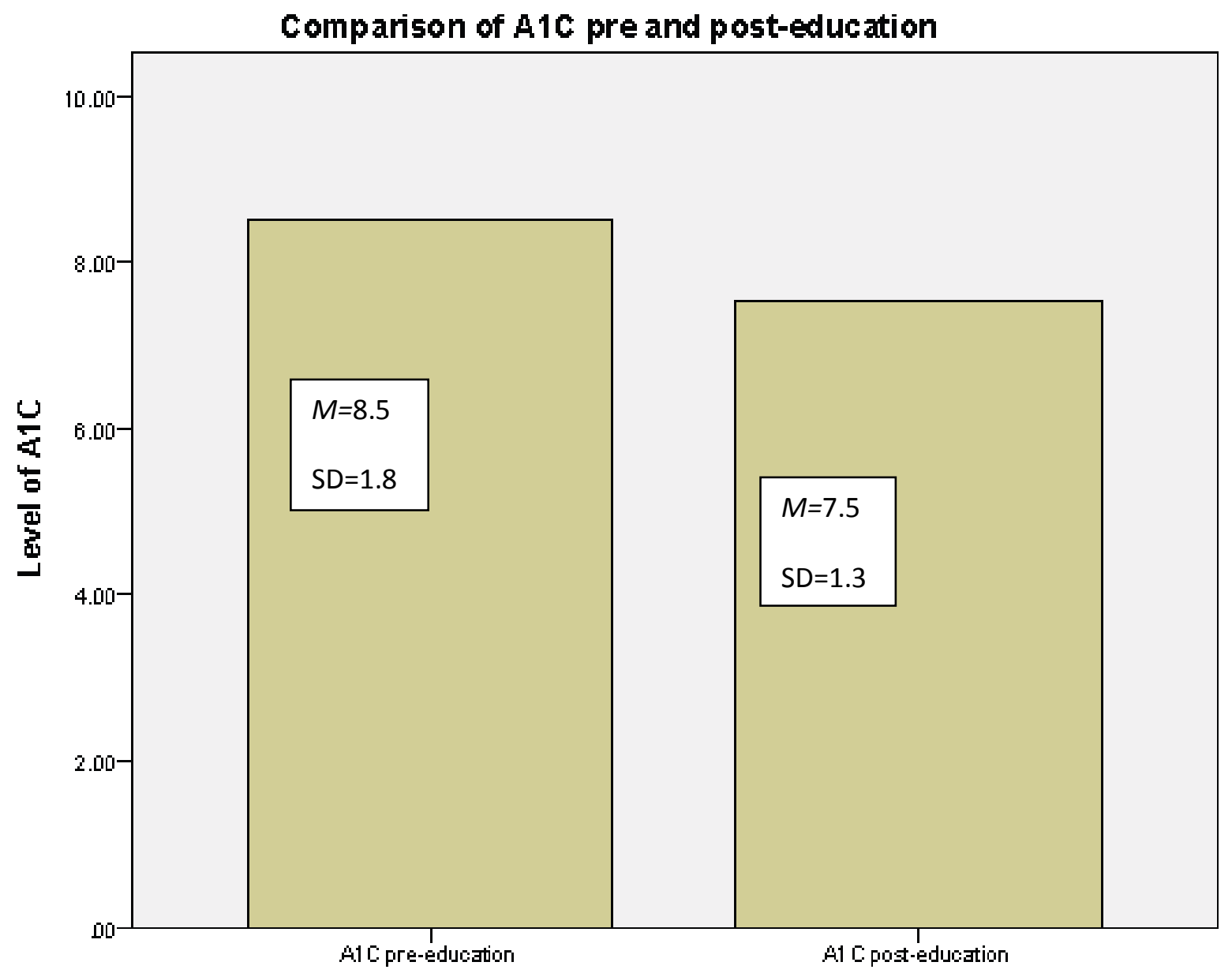

Figure 3. Comparison of A1C pre and post-education. 
Appendix C

Program Materials 


\section{Manual Contents}

Flyer for diabetes education

Participant assessment form

Example of class schedule

Curriculum outline from the Johns Hopkins Comprehensive

Diabetes Center

Goal sheet

Education evaluation 


\section{The Johns Hopkins \\ We'll guide you to successful management of diabetes.}

\section{RESOURCES:}

3 HOUR GROUP EDUCATION CLASSES

OR

INDIVIDUAL APPOINTMENTS WITH ONE OF OUR

CERTIFIED DIABETES EDUCATORS

Managing diabetes starts with EDUCATION and continues with caring. Give us a call - it's a lot easier to handle, if you don't have to handle it alone.

\section{Call 410-955-7139 to REGISTER}

All Medical Insurance Plans are considered. HURRY while seats are available.

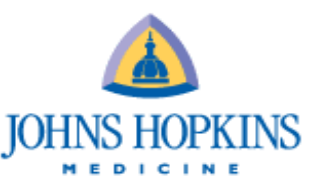




\section{ASSESSMENT}

Name

MR\#

Primary Care Provider

How referred:

self

PCP

endocrinologist

other

Diabetes: $\square$ type 1 (250.01); $\square$ type 1 (250.03 uncontrolled); $\square$ type $2(250.00) ; \quad \square$ type 2 (250.02 uncontrolled)

Date of diagnosis:

Medical and Social History:

Knowledge/Skill level: (1) No knowledge, (2) Needs Review Assistance, (3) Demonstrates Competency. (N/A) Not Applicable

\begin{tabular}{|l|l|l|l|l|}
\hline $\begin{array}{l}\text { Diabetes Self-Management Education Content } \\
\text { Area }\end{array}$ & \multicolumn{3}{|c|}{ Areas in which patient evidences lack of understanding } \\
\hline $\begin{array}{l}\text { Describing the diabetes disease process and } \\
\text { treatment options }\end{array}$ & $\begin{array}{l}\text { Pre- } \\
\text { class }\end{array}$ & Pre-class comments & $\begin{array}{l}\text { Follow- } \\
\text { up }\end{array}$ & Comments \\
\hline $\begin{array}{l}\text { Incorporating appropriate nutritional } \\
\text { management }\end{array}$ & & & & \\
\hline $\begin{array}{l}\text { Incorporating physical activity into lifestyle } \\
\text { Utilizing medications (if applicable) for }\end{array}$ & & & & \\
\hline $\begin{array}{l}\text { Monitoring blood glucose, urine ketones } \\
\text { (when appropriate), and using the results to } \\
\text { improve control }\end{array}$ & & & & \\
\hline $\begin{array}{l}\text { Preventing, detecting, and treating acute } \\
\text { complications }\end{array}$ & & & & \\
\hline $\begin{array}{l}\text { Preventing (through risk reduction behavior), } \\
\text { detecting, and treating chronic complications }\end{array}$ & & & & \\
\hline $\begin{array}{l}\text { Goal setting to promote health, and problem } \\
\text { solving for daily living }\end{array}$ & & & & \\
\hline $\begin{array}{l}\text { Integrating psychosocial adjustment to daily } \\
\text { life }\end{array}$ & & & & \\
\hline $\begin{array}{l}\text { Promoting preconception care, management } \\
\text { during pregnancy, and gestational diabetes } \\
\text { management (if applicable) }\end{array}$ & & & & \\
\hline
\end{tabular}


Meter Brand:

Appropriate: Yes No

New meter recommended
Needed Instruction: Yes No due

Monitoring Freq.:

to

\begin{tabular}{|l|l|}
\hline Support person: & \\
\hline Exercise routine: & \\
\hline Barriers to control: & \\
\hline $\begin{array}{l}\text { Concerns/questions } \\
\text { To be addressed: }\end{array}$ & \\
\hline
\end{tabular}

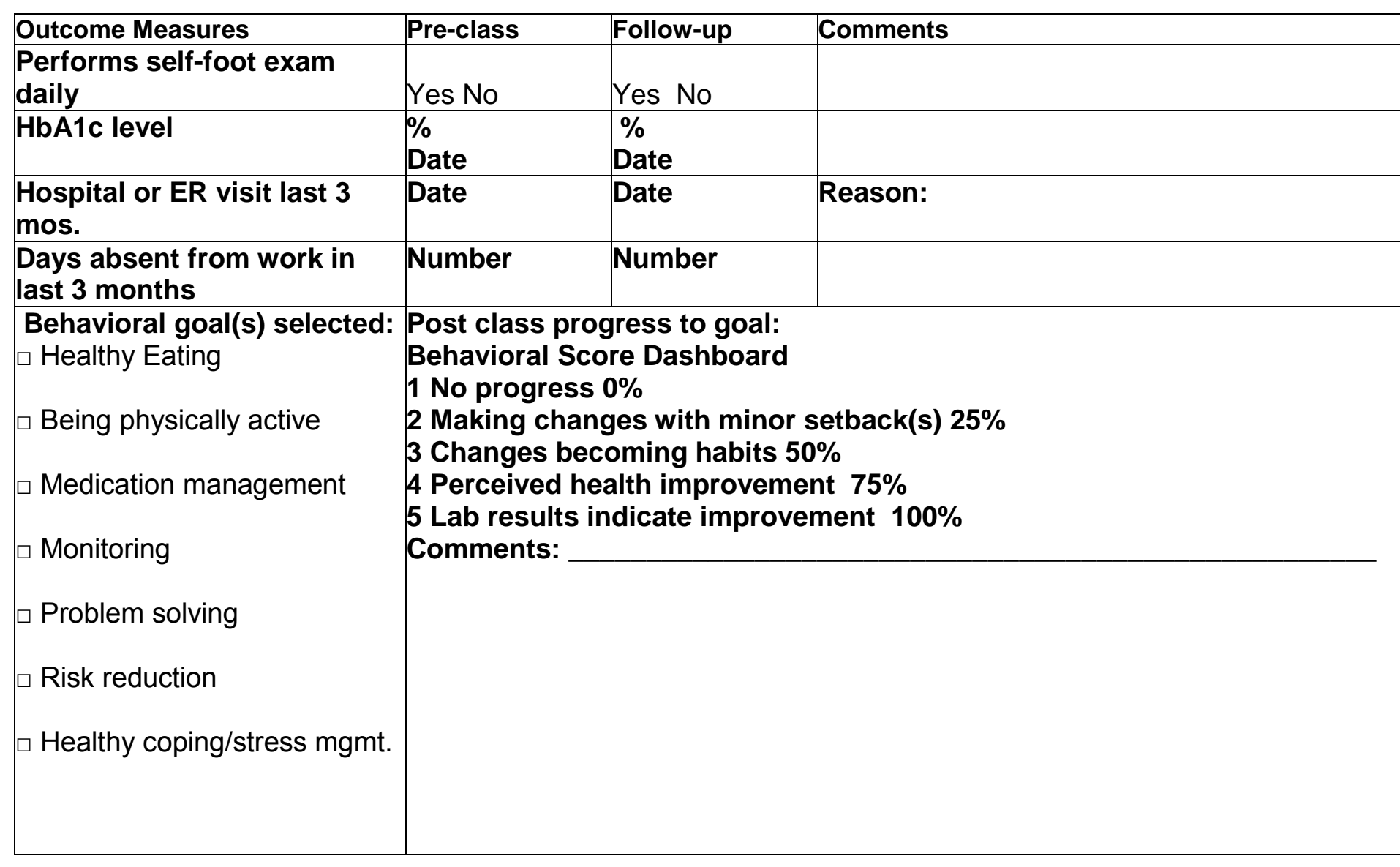




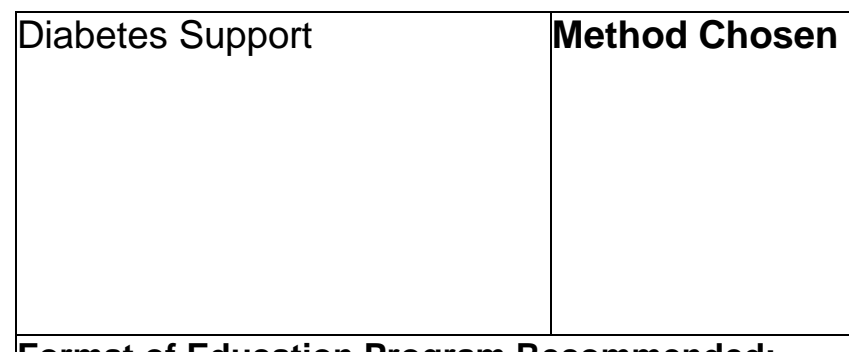

\section{Format of Education Program Recommended:}

\begin{tabular}{|c|c|}
\hline Group: & Individual instruction: \\
\hline \multirow[t]{2}{*}{3 hour class } & $\begin{array}{l}\text { Preferred / Requested: } \\
\square \text { Learning Barrier: Impairment: } \square \text { Visual, } \square \text { Hearing, } \square \text { Cognitively, } \square \\
\text { Psychologically, } \\
\square \text { Low Literacy English as a second language } \\
\square \text { Other: }\end{array}$ \\
\hline & $\square$ No Group Class available within time frame needed. \\
\hline
\end{tabular}

Notes:

Reviewed with CDE:

Pre-Program Interviewer Signature: Date: Post-Program Interviewer Signature: Date: 


\section{The Johns Hopkins Comprehensive Diabetes Center Employee Diabetes Education Program \\ JHOC Conference Room \\ 9:00-12:00}

9:00-9:30 Registration \& Introductions

Overview of Program

What is Diabetes?

- Making the diagnosis

- Blood glucose goals

- Complications

- Self-monitoring

- Why check your own glucose?

\section{9:30-10:30 Nutrition Basics}

- How does Nutrition Therapy relate to Diabetes and what are the goals

- How does food affect your glucose

- No more DIETS!! It's all about life-style changes

- Why are Portions so important and how do I stop from feeling hungry

- All about Carbohydrates and reading food labels

10:30-10:45 Break

10:45-11:15 Self Empowerment \& Understanding medications

- Navigating the maze of diabetes medications their actions and side effects

- Understanding the consequences of uncontrolled diabetes

- Reducing the risk of complications

11:15-11:45 Physical Activity and SelfCare/Sick Day Rules

11:45-12:00 Choosing goals and evaluation Making your follow-up appointment with the diabetes educator 


\title{
Education Manual of Curriculum for Worksite Diabetes Education
}

\section{Table of Contents}

TABLE OF CONTENTS

\author{
Understanding Diabetes \\ Monitoring your Diabetes \\ Nutrition \\ Nutrition Labeling \\ Insulin and Oral Medications \\ Managing Emergencies \\ Complications of Diabetes \\ Exercise and Physical Activity \\ Personal Health Habits \\ Goal Setting
}

Note: Pertinent chapters are taken from the curriculum used at the Johns Hopkins Comprehensive Diabetes Center education classes and visits. The full education manual is available at the center from the American Diabetes Association Program Coordinator, Susan Renda, MS, CRNP, CDE. 


\section{My Personal Contract Johns Hopkins Diabetes Education Program}

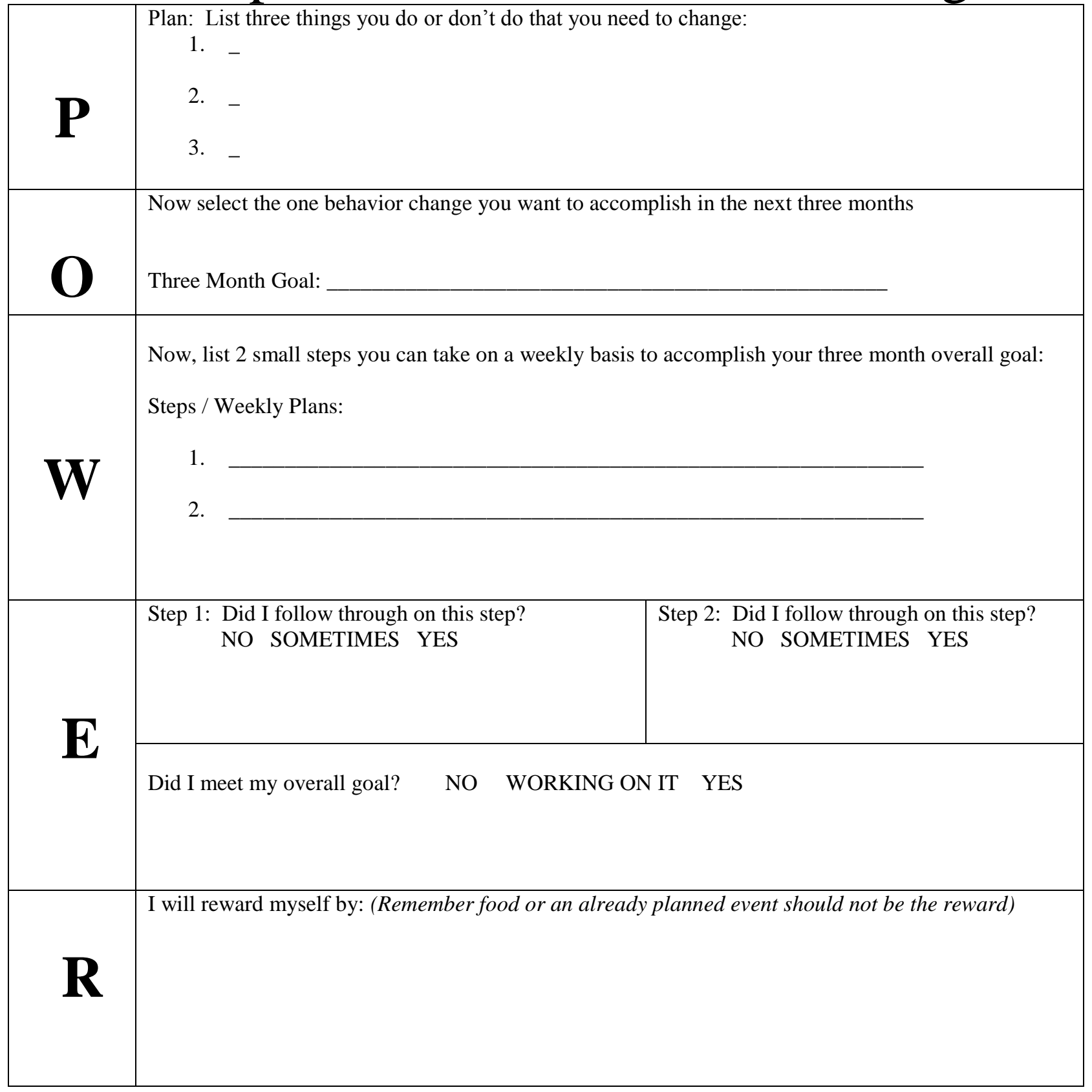

\begin{tabular}{|l|l|l|}
\hline Lab & $\begin{array}{l}\text { Pre-Program } \\
\text { Date and Result }\end{array}$ & $\begin{array}{l}\text { Post-Program } \\
\text { Date and Result }\end{array}$ \\
\hline HbA1c & \multicolumn{3}{|l}{} \\
\hline Date: & Signature:
\end{tabular}

Bring this contract back with you to the follow-up visit

on:

pm at:

am / 


\section{JOHNS HOPKINS DIABETES CENTER EDUCATION PROGRAM EVALUATION}

Course Name: Diabetes Education Program Training Location: JHOC

Participant Name (optional): Date:

\section{INSTRUCTIONS}

Please circle your response to the items. Rate aspects of the course on a 1 to 5 scale 1 equals "strongly disagree" and 5 equals "strongly agree." 1 represents the lowest and most negative impression on the scale, 3 represents an adequate impression, and 5 represents the highest and most positive impression. Choose $\mathrm{N} / \mathrm{A}$ if the item is not appropriate or not applicable to this education program. Your feedback is sincerely appreciated. Thank you.

COURSE CONTENT: (Circle your response to each item.)

This course lived up to my expectations.

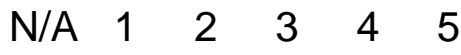

The content is relevant to my diabetes goals.

$\mathrm{N} / \mathrm{A} \quad 1 \quad 2 \quad 2 \quad 3 \quad 4 \quad 5$

COURSE DESIGN: (Circle your response to each item.)

The course activities stimulated my learning.

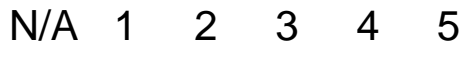

The pace of this course is appropriate.

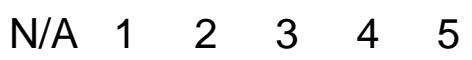

COURSE ENVIRONMENT: (Circle your response to each item.)

The training facility was comfortable.

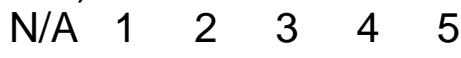

The staff was professional and courteous.

$\mathrm{N} / \mathrm{A} \quad 1 \quad 2 \quad 2 \quad 3 \quad 4 \quad 5$

COURSE RESULTS: (Circle your response to each item.)

The information presented on diabetes management increased my awareness of how to live a healthier life.

I would highly recommend this class to a friend.

$\mathrm{N} / \mathrm{A} \quad 1 \quad 2 \quad 3 \quad 4 \quad 5$

OTHER:

What other improvements would you recommend in this education program?

What is least valuable about this education program?

What is most valuable about this education program? 
EDUCATION INSTRUCTOR (FACILITATOR) (Circle your response to each item.)

\section{Nurse Practitioner/Diabetes Educator}

$\begin{array}{lllllll}\text { The instructor was very knowledgeable on her subject. } & \text { N/A } & 1 & 2 & 3 & 4 & 5\end{array}$

$\begin{array}{lllllll}\text { The instructor was helpful. } & \text { N/A } & 1 & 2 & 3 & 4 & 5\end{array}$

Comments:

\section{Nutritionist /Diabetes Educator}

$\begin{array}{lllllll}\text { The instructor was very knowledgeable on her subject. } & \text { N/A } & 1 & 2 & 3 & 4 & 5\end{array}$

$\begin{array}{lllllll}\text { The instructor was helpful. } & \text { N/A } & 1 & 2 & 3 & 4 & 5\end{array}$

Comments:

NA=Not applicable 1=Strongly disagree 2=Disagree 3=Neither agree/nor disagree 4=Agree $5=$ Strongly agree

\section{Additional Comments:}


Appendix D

Approval Forms 


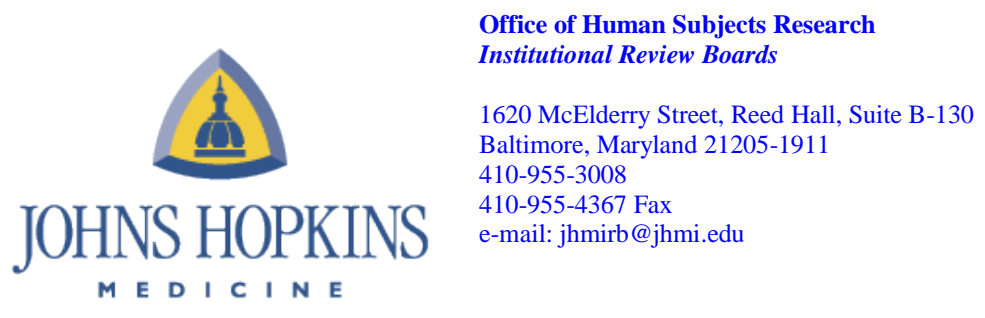

Date: September 16, 2013

\section{NEW APPLICATION APPROVAL}

$\begin{array}{ll}\text { Review Type: } & \text { Expedited } \\ \text { PI Name: } & \text { Kathleen Becker } \\ \text { Study \#: } & \text { NA_ooo88149 } \\ \text { Study Name: } & \text { An Evaluation of a Worksite Diabetes Education Program for Employees with } \\ \text { Committee } & \text { Diabetes at a Large Urban Medical Center } \\ \text { Chair: } & \text { Susan Bassett } \\ \text { Committee: } & \text { JHM-IRB X }\end{array}$

Date of review: September 12, 2013

Date of approval: September 12, 2013

Date of expiration: September 11, 2014

The JHM IRB approved the above-referenced New Application.

Date of Approval and Expiration Date: The approval and expiration date for this research are listed above. If the approval lapses, the research must stop and you must submit a request to the IRB to determine whether it is in the best interests of individual participants to continue with treatment interventions.

Changes in Research: All proposed changes to the research must be submitted using an eIRB Change in Research application. The changes must be approved by the JHM IRB prior to implementation, with the following exception: changes made to eliminate apparent immediate hazards to participants may be made immediately, and promptly reported to the JHM IRB.

Continuing Review: Continuing Review Applications should be submitted at least 6 weeks prior to the study expiration date. Failure to allow sufficient time for review may result in a lapse of approval. If the Continuing Review Application is not submitted prior to the expiration date, your study will be terminated and a New Application must be submitted to reinitiate the research.

Unanticipated Problems: You must inform the IRB of any unanticipated problems involving risks to 
participants or others.

If this research has a commercial sponsor, the research may not start until the sponsor and JHU have signed a contract.

\section{Study documents:}

\section{Written Consent:}

Only consent forms with a valid approval stamp may be presented to participants. All consent forms signed by subjects enrolled in the study should be retained on file. The Office of Human Subjects Research conducts periodic compliance monitoring of protocol records, and consent documentation is part of such monitoring.

FINAL_Becker_NA_ooo88149_CF_091213 NoLogo.doc

Recruitment Materials:

recruitment_ad diabetes center.doc

HIPAA Form 4:

form 4.doc

Additional Supplemental Study Documents:

Johns Hopkins Diabetes Center Assessment form.docx

JOHNS HOPKINS DIABETES CENTER EVALUATION.docx

Example schedule for group education class.docx

\section{eFormA:}

eForm A

\section{Study Team Members:}

Susan Renda

The Johns Hopkins Institutions operates under multiple Federal-Wide Assurances: The Johns Hopkins University School of Medicine FWAooo05752, The Johns Hopkins University School of Nursing - FWAoooo6088, The Johns Hopkins Hospital and Johns Hopkins Health Systems - FWAoooo6087, Johns Hopkins Bayview Medical Center - FWAoooo6089, Howard County General Hospital - FWA0ooo5743, Hugo W. Moser Research Institute at Kennedy Krieger, Inc. - FWAoooo5719, Johns Hopkins Community Physicians - FWA00002251, Suburban Hospital and Health System - FWAoooo5924 


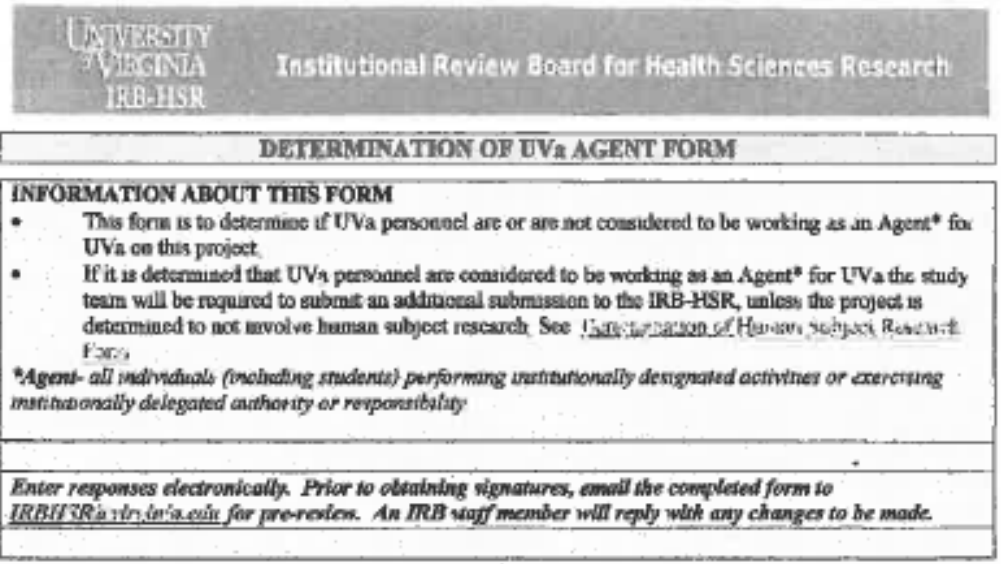

Name of lidividual to be Working oe Project

Email:

Phone:

UVa Meesenger Mail Box \#

ProjectProtocol Title if Known'

Explain your nole in the project: (200 wards or less)

Explain the reason for traveling so the outside iestitution.
Suran Renda

snov thathvirginin od

410-744-1688

amertdh(G) virginia edu

口 Üknown or

Trite: An Evaluation of a Worksite Diabctes Educatioe Program fox Employess with Diabetes at a Large Urtan Medikal Certer

As a burse proctitionet and cerfified Jiabotis education in

the Hookins dabutes catter I wil encourages Johes

Hopkins exployecas to attend our diabetes edicabon group alasses and individuel visite I will gather data on Alc, self managenent goels, satistacion with eflucabou, Ieported ding absert from work, and reponted visits to the cwergency mown Paiticipasts will have a three moeth follow-up to the diabebes center, which is stamdard proctice A de-idenified data get will be criated of the data in oeder to compase thee wonthe before educatoon sand tirex moofiss affer. I will cbtain consent to evemine the data at the instal echroation vist I will be overseen by my Hopkins PI

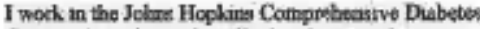
Center where the stady will take phee involving out currat diabetres educestion program Ail subjaxis will be froun Hopkits, the PI is a Johes Hopolias Schiool of Nursmg facealty, and the fohns Hopkins IRB will oversee the stady

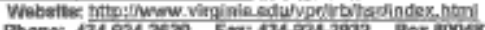


1. Answer the following questions:

Yes ${ }_{\text {No I }}$ I was imvolved in the design of this research project.

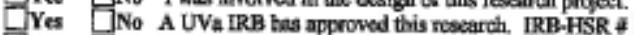

Yes No Fusding to canduct this research will come from UVa.

Yes No The only reason I am traveling to this outside institution is to wock on this research.

$\square$ Yes $\square \mathrm{Ni}_{0}$ Working an this rescarch is required for ny degroo progmm.

2. I cenfirm that

Yes $\square$ No I am a student, emplogee and/or faculty member of the Univensity of Virginia.

Y Yes Do My work on this project will be oversen by the Principal Investigator and the IRB at the outside institution. This inchudes completing any training in human subjest resesuch protection as required by the outside IRB

$\square$ Yes $\square$ No I will ponumanicate with the IRB and the Contracts Oefice, to determine what approvals may be seeded, prior to reeciving any data from the outside institution.

$\overline{\mathbf{O R}}$

3. I confirm that :

XYes $\square$ No Idesigned this research.

$\triangle \mathrm{Yea}$ No I an a stadent at UVa but am employed by another institution.

QYes Lino All subjects will be enrolied at this cutside institution,

$\triangle$ Yes $\square$ No The research will be overseca by their IRB and, if applicable, their HIPAA Privecy

Board. This inchades completing any traiking in human subject reseselh protections as sequired by the cetside IRB.

$\triangle Y$ Yes $\square$ No There is no fimding for this atunty.

$\triangle$ Yes $\square$ No I lave botified the outside IRB that an UVa IRB will not be overseeing my work. ATTACH COPY OF OUTSIDE IRB APPROVAL.

Susen Rienda MS, CRRNP, CDE DNP student Universith of Virgina Sstaopt of

Nurrang

Primted Nams of Person Completing this Focm

$7 / 16 / 1$

Re

Signelure of Person Completing this Rom

$9 / 16 / 13$

FOR IRB-HSR OFFICE USE ONLY

¿UVa personnel are net considered to be werking as an Agunt for UVa on this project.

No sppeovals from the UVa IRB-HSR are required.

$\square$ UVa persoencl are coesidered to be working as an Agent for UVa ce this project.

Subanit a resesnch applieation to the UVa IRB.HER

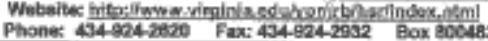

Verslon data:02-2-12

Page 3 of 4 


\section{JOHNS HOPKINS EMPLOYEES, DO YOU HAVE DIABETES? COME TO DIABETES SELF- MANAGEMENT EDUCATION AT THE JOHNS HOPKINS DIABETES CENTER IN THE OUTPATIENT CENTER!}

Participate in a study, "An Evaluation of a Worksite Diabetes Education Program for Employees with Diabetes at a Large Urban Medical Center" which looks at diabetes self-management at your workplace and how it impacts your ability to control diabetes.

You can participate if you are a current employee at Johns Hopkins Medical Institution between 18 and 75 years old with a diagnosis of diabetes for at least 3 months.

Schedule either a group class or an individual appointment with a certified diabetes educator who is a dietitian or nurse practitioner. Three months later, have an individual appointment for follow-up to assess how you are doing with your diabetes.

\section{HOUR GROUP EDUCATION CLASSES OR INDIVIDUAL APPOINTMENTS}

\section{WITH ONE OF OUR CERTIFIED DIABETES EDUCATORS}

\section{Call or email Susan Renda}

For more information and how

to schedule

410-955-7140

srenda1@jhu.edu 


\section{JOHNS HOPKINS}

Approved September 12, 2013
Date: September 12, 2013

Principal Inves tigator: Kathleen Becker

Application Ho.: HA_00088149

Pationt ID . Plate

\section{RESEARCH PARTICIPANT INFORMED CONSENT AND PRIVACY AUTHORIZATION FORM}

Protocol Title:

Application No:

Principal Investigator: Kathleen Becker, DNP, ANP-BC

Johns Hopkins University School of Nursing

525 N. Wolfe Street

Baltimore MD 21205

(410) $955-4766$

1. What you should know about this study:

- You are being asked to join a research study because you have diabetes and you are an employee.

- This consent form explains the research study and your part in the study.

- Please read it carefully and take as much time as you need.

- Please ask questions at any time about anything you do not understand.

- You area volunteer. If you join the study, you can change your mind later. You can decide not to take part or you can quit at any time. There will be no penalty or loss of benefits if you decide to quit the study.

- During the study, we will tell you if we leam any new information that might affect whether you wish to continue to be in the study.

- Ask your study nurse or the study team to explain any words or information in this informed consent that you do not understand.

- If you have clinical tests done as part of this research study, a statement will be added to your medical record that you are in this research study. Results from any clinical tests you have will be included in your medical record. Doctors outside of Johns Hopkins may not have access to this information. You can ask the research team to send this information to any of your doctors.

\section{Why is this research being done?}

This research is being done to study the outcomes of a worksite diabetes education program for employees at Johns Hopkins Medical Institution.

We will look at diabetes self-management at your workplace and how it impacts your ability to control diabetes.

Combined hromed Consert/ inthoriatian March 2012 Versian 13 


\section{JOHNS HOPKINS}

Approved September 12, 2013
Date: September 12,2013

Principal Inves tizator: Kathleen Becker

Application No.: HA_00088149

We will collect information from you including A $1 \mathrm{C}$ level (the 3 month "average" of your blood sugar), days absent from work, wisits to the emergency departmenthospital, ability to achieve a diabetes selfmanagement goal, and satisfaction with diabetes education.

Adults diagnosed with diabetes for at least 3 months and are current employees at Johns Hopkins may join the study.

How many people will be in this study?

Up to 70 people will be able to join the study from Johns Hopkins.

\section{What will happen if you join this study?}

If you agree to be in this study, we will ask you to do the following things:

Participate in either a group education class or an individual appointment with a certified diabetes educator who is a dietitian or nurse practitioner.

Participation involves two visits.

\section{Visit 1:}

You will be asked to come 15 minutes before the scheduled time of class or appointment to receive explanation of the study, sign the informed consent, and to complete a witten intake form regularly used in the Diabetes Center which includes questions about number of emergency department/hospitalization visits.

For the purposes of this research study, there will be an additional question about number of days absent from work in the last three months.

With diabetes education at the Diabetes Center, you would normally be asked to share blood lab results of your most recent $\mathrm{A} 1 \mathrm{C}$ or have a blood test to obtain a current $\mathrm{A} 1 \mathrm{C}$, as is the standard protocol for patients coming to the Diabetes Center appointments or classes.

At the begining of the appointment or just before class starts, the certified diabetes educator will briefly review the information on the intake form with you and will give you a chance to ask questions about the program. The intake review takes less than five minutes.

\section{Educational sessiont}

Education material from the Diabetes Center curriculum about diabetes self-management topics of understanding diabetes, nutrition, monitoring, medications, physical activity, and sick day rules will be presented and reviewed with you by the certified diabetes educator in a group class or at the individual appointment.

At the end of the class or appointment, you will be asked to choose a self-management goal from one of seven self-management areas to work on in the next three months and to wite down steps to attain that goal on a sheet used in the Diabetes Center. You will also be asked to evaluate the education you have received.

You will be asked to make a 30 minute follow-up appointment for three months. 


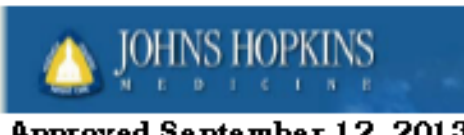

Date: September 12, 2013

Principal Inves tizator: Kathleen Becker

Application No.: NA_00088149

Visit 2 ( 3 month follow-u visit):

Participants in education classes and appointments are always asked to retum to the Diabetes Center for a follow-up appointment in three months to check how you are doing in reaching your goal, whether you have had emergency room or hospital visits since the education visit, and to review or obtain an updated A1C lab test.

After the end of the study, you may choose to continue care and education at the Diabetes Center.

\section{How bng will you be in the study?}

You will be in this study for 3 months with 2 visits.

\section{What are the risks or discomforts of the study?}

Confidentiality: Information is kept confidential as it is with standard care in the Diabetes Center. However, there is the risk that information about you may become known to people outside this study.

Questions/Questionnaires: Y ou may get tired or bored when we are asking you questions or you are completing questionnaires. You do not have to answer any question you do not want to answer.

\section{Are there benefits to being in the study?}

There may or may not be a direct benefit to you from being in this study

If you take part in this study, you may help others in the future.

6. What are your options if you do not want to be in the study?

If you decide not to join this study, other options are available. You do not have to join this study to get. treatment. Other treatments include appointments or education classes not specifically created for employees as are currently available in the Diabetes Center.

You do not have to join this study. If you do not join, your care and employment at Johns Hopkins will not be affected.

7. Will it cost you anything to be in this study?

Education at the Diabetes Center is billed to your health insurance.

8. Will you be paid if you join this study?

No.

9. Can you leave the study early?

- You can agree to be in the study now and change your mind later.

- If you wish to stop, please tell us tight away.

- Leaving this study early will not stop you from getting regular medical care

- If you leave the study early, Johns Hopkins may use or give out your health information that it already has if the information is needed for this study or any follow-up activities.

10. Why might we take you out of the study early?

You may be taken out of the study if:

- You become pregnant. 


\section{JOHNS HOPKINS}

Approved September 12, 2013

Date: September 12,2013

Principal Inves tizator: Kathleen Becker

Application Ho.: NA_00088149

- The study is cancelled.

- You are no longer employed at Johns Hopkins.

- There may be other reasons to take you out of the study that we do not know at this time.

If you are taken out of the study early, Johns Hopkins may use or give out your health information that it already has if the information is needed for this study or any follow-up activities.

\section{How will your privacy be protected?}

Johns Hopkins has rules to protect information about you. Federal and state laws al so protect your privacy.

The research team working on the study will collect information about you. This includes things learned from the procedures described in this consent form They may also collect other information including your name, address, date of birth, and other details.

Generally, only people on the research team will know your identity and that you are in the research study. However, sometimes other people at Johns Hopkins may see or give out your information. These include people who review research studies, their staff, lawyers, or other Johns Hopkins staff.

People outside of Johns Hopkins may need to see your information for this study. Examples include government groups (such as the Food and Drug Administration), safety monitors, other hospitals in the study and comparies that sponsor the study.

We cannot do this study without your permission to use and give out your information. You do not have to give us this permission. If you do not, then you may not join this study.

We will use and disclose your information only as described in this form and in our Notice of Privacy Practices, however, people outside Hopkins who receive your information may not be covered by this promise. We try to make sure that everyone who needs to see your information keeps it confidential but we cannot guarantee this.

The use and disclosure of your information has no time limit. You may cancel your permission to use and disclose your information at any time by notifying the Principal Investigator of this study by phone or in witing. If you contact the Principal Investigat or by phone, you must follow-up with a witten request that includes the study number and your contact information. The Principal Investigator's name, address, phone and fax information are on page one of this consent form.

If you do cancel your permission to use and disclose your information, your part in this study will end and no further information about you will be collected. Your cancellation would not affect information already collected in the study.

12. Will the study require any of your other health care providers to share your health inform ation with the researchers of this study?

As a part of this study, the researchers may ask to see your health care records from your other health care providers for the purpose of obtaining your lab results of $\mathrm{A} 1 \mathrm{C}$ as would be done nomally for Diabetes Center classes and appointments. 
JOHNS HOPKINS
approved September 12, 2013

Date: September 12, 2013

Principal Inves tizator: Kathleen Becker

Application No.: HA_00088149

13. What other things should you know about this research study?

a. What is the Institutional Review Board (IRB) and how does it protect you?

The Johns Hopkins Medicine IRB is made up of:

- Doctors

- Nurses

- Ethicists

- Non-scientists

- and people from the local community.

The $\mathbb{R B}$ reviews human research studies. It protects the rights and wel fare of the people taking part in those studies. You may contact the $\mathbb{R B}$ if you have questions about your rights as a participant or if you think you have not been treated fairly. The IRB office number is 410-955-3008. You may also call this number for other questions, concems or complaints about the research.

b. What do you do if you have questions about the study?

Call the principal investigator, Dr. Kathleen Beckerat 410-614-5304 or co-investigator Susan

Renda, CRNP at 470955-7139 If you wish, you may contact the principal investigator by letter or by fax. The address and fax number are on page one of this consent form. If you cannot reach the principal investigator or wish to talk to someone else, call the $\mathbb{R B}$ office at 410-955-3008.

c. What happens to Data that are collected in the study?

Scientists at Johns Hopkins work to find the causes and cures of disease. The data collected from you during this study are important to both this study and to future research.

If you join this study:

- You will not own the data given by you to the investigators for this research.

- Johns Hopkins research may study your data collected from you.

- If data is in a form that identifies you, Johns Hopkins may use them for future research orly with your consent or $\mathbb{R B}$ approval.

- If data, tissue, blood or other specimens are in a form that we believe does not identify you, they may be shared with other academic medical centers, non-profit organizations, corporate sponsors and other commercial companies without your consent or $\mathbb{R B}$ approval.

- You will not own any product or idea created by the researchers working on this study.

- You will not receive any firancial benefit from the creation, use or sale of such a product or idea.

d. What are the Organizations that are part of Johns Hopkins?

Johns Hopkins includes the following:

- The Johns Hopkins University

- The Johns Hopkins Hospital

- Johns Hopkins Bayview Medical Center

- Houard County General Hospital

- Johns Hopkins Community Physicians.

- Suburban Hospital

- Sibley Memorial Hospital 


\section{JOHNS HOPKINS}

Approved September 12, 2013
Date: September 12, 2013

Principal Inves tizator: Kathleen Becker

Application Ho.: HA_00088149

14. What does your signature on this consent form mean?

Your signature on this form means that:

- you understand the information given to you in this form

- you accept the provisions in the form

- you agree to join the study

You will not give up any legal rights by signing this consent form

WE WILL GIVE YOU A COPY OF THIS SIGNED AND DATED CONSENT FORM

NOTE: A COPY OF THE SIGNED, DATED CONSENT FORM MUST BE KEPT BY THE PRINCIPAL INVE STIGATOR; A COPY MUST BE GIVEN TO THE PARTICIPANT; AND, IF APPROPRIATE A COPY OF THE CONSE NT FORM MUST BE PLACED IN THE PARTICIPANT'S MEDICAL RE CORD

ONL Y CONSENT FORMS THAT INCLUDE THE JOHNS HOPKINS MEDICINE LOGO CAN BE USED FOR CONSENTING RE SEARCH PARTICIPANTS. IF THIS CONSENT FORM DOES NOT HAVE A JOHNS HOPKINS MEDICINE LOGO, DO NOT USE IT TO CONSENT RESE ARCH PARTICIPANTS. 